Engineering Earth 

Stanley D. Brunn

Editor

\section{Engineering Earth}

The Impacts of Megaengineering Projects

Springer 


\section{Editor}

Prof. Stanley D. Brunn

Department of Geography

University of Kentucky

40506-0027 Lexington

KY, USA

brunn@uky.edu

Printed in 3 volumes

ISBN 978-90-481-9919-8

e-ISBN 978-90-481-9920-4

DOI 10.1007/978-90-481-9920-4

Springer Dordrecht Heidelberg London New York

(C) Springer Science+Business Media B.V. 2011

No part of this work may be reproduced, stored in a retrieval system, or transmitted in any form or by any means, electronic, mechanical, photocopying, microfilming, recording or otherwise, without written permission from the Publisher, with the exception of any material supplied specifically for the purpose of being entered and executed on a computer system, for exclusive use by the purchaser of the work.

Cover Design: Adam White

Printed on acid-free paper

Springer is part of Springer Science+Business Media (www.springer.com) 


\section{Gilbert F. White}

pioneering scientist

transdisciplinarian

humanitarian

peace activist

international scholarly diplomat 



\section{Preface}

This volume is an outgrowth of an international and interdisciplinary conference that I initiated and co-organized at the University of Kentucky in July 2008. The purpose of this conference, the title the same as this volume, was to bring together a group of scholars from different disciplines and perspectives who are interested in megaengineering projects who usually do not communicate with each other, even if they study the same topic. These included dams, highways, and mining. The conference was successful because the fifty presentations by social, engineering, and environmental scientists from nine countries addressed the impacts of various megaprojects and because it demonstrated the need for increased dialogue and collaboration.

The conference was dedicated to Dr. Gilbert White, who, for more than seven decades was an enthusiastic advocate of those conducting research on important global resource and public policy initiatives and the perception of natural and technological hazards at local and international scales. He was also keenly interested in disseminating research findings to those in the classroom and a wider public. Throughout his professional life, including at TVA, Haverford College, the University of Chicago, and the University of Colorado, he influenced generations of students and professionals of all ages and ranks and those with varying professional interests. Many scholars today, including many who contributed to this volume and who work at the geography/technology/policy/environment interfaces trace some of their intellectual roots to Gil. He received many national and international awards for his achievements, including the National Medal of Science presented to him by President Clinton in 2000. As a long time friend, a fellow Quaker, a solid humanitarian, a peace activist, and international scholarly diplomat, it is fitting to dedicate this volume to him.

As I was organizing the conference and also editing this volume, I was asked often how I became interested in the engineering earth topic and megaprojects specifically. The simple answer is that they are an outgrowth of where I have lived and the many conversations and interactions with friends over the years. For many geographers of my generation, we received training in the natural, social, and policy sciences, so studying the impacts of large engineering projects from economic, cultural, and environmental perspectives at local and global scales was understandable. During my lifetime I have witnessed in the many places I have lived, taught and traveled the construction of various megaprojects and 
their impacts on people's daily lives. These include memories of nuclear testing years of the 1950s and 1960s, the construction of the Interstate Highway System, mass-produced "cookie cutter" suburbs and the "malling and Wal-Martization" of America," the computer worlds before the Internet, GIS, and Google Earth, and social justice issues that result from the social engineering of political America. My research career includes projects examining various geography/technology issues, including the impacts of Three Mile Island in 1979 with Jim Johnson and Don Zeigler, co-editing volumes on the geographies of information and communication and E-commerce with my colleague Tom Leinbach, co-editing with Susan Cutter and J. W. Harrington a centennial volume for the Association of American Geographers on geography and technology, and editing an interdisciplinary book on Wal-Mart. Also I have benefitted from numerous conversations with my own colleagues, especially Matt Zook and Karl Raitz, but also my many friends at the University of Kentucky in biology, astronomy, landscape architecture, economics, engineering, public health, education, social theory, and the Appalachian Center.

Living in Kentucky since 1980 and teaching undergraduate classes and seminars on various topics have kept me sensitive to engineering earth questions in my backyard. There are a number of megaprojects that Kentuckians can easily identify. These include the destruction to communities and ecosystems brought on by mountain top removal, the burial of low level nerve gas in rotting canisters stored at the Bluegrass Army Depot near Richmond, the social and environmental engineering of the Bluegrass as an amenity region, the drawing down of water in the Cumberland River dam which negatively impacted the local recreation economies, and the construction of various architectural, landscaping and engineering projects in Lexington for its hosting the World Equestrian Games in fall 2010.

A series of other events have also affected my thinking about nature/society issues in recent years. These include the on-going wars in Iraq and Afghanistan, which are/were certainly megaengineering projects with impacts on economies, culture, and environments, the devastation resulting from Hurricane Katrina in the fall of 2005, the BP oil spill in the Gulf of Mexico in Spring 2010, the construction and enforcement of security landscapes since $9 / 11$, and the constant searching for energy alternatives. A key ingredient in my thinking was the field trip at the annual meetings of the Southeast Division, Association of American Geographers in Morgantown, West Virginia in November 2006 that was organized by my good friend, Ken Martis. He showed us firsthand the environmental destruction caused by mountaintop removal, not only the heavy machinery used, but the dynamiting. Understanding fully the impacts of any of the above projects does not come from research within a single discipline, but rather thinking outside our intellectual comfort zones.

In many ways the July 2008 conference was, and this book is, about "bridges," that is, bridges that span "spaces" where the dialogue and scholarly research have often been narrowly conceived and carried out. I am describing those worlds where scholars operate in parallel universes. The conference and this volume are efforts that transcend the all too familiar and intellectually comfortable worlds 
of those interested primarily in economic, environmental, cultural, or engineering solutions as solutions to megaengineering impact questions. I would extend the need for intellectually bridge-building efforts and communities to include those interested in sustainability, empowering (and re-engineering) local institutions, humane landscape designing, megainstitutions (universities, churches, entertainment complexes), alternative energy projects, tourism and event planning, virtual communities, and large scale ICT projects.

Organizing this conference and editing this book with contributors from the social, environmental, and engineering scientists have been enjoyable learning experiences. But neither could have been accomplished without the help of a wide network of local and global friends or the Internet. I have "met" many new scholars, especially from the engineering sciences, via email. The first emails were sent in late November 2006. Since then I have sent or received nearly 12,000 emails from local and international friends, conference participants, authors, reviewers, financial supporters, and the publisher. Most of these exchanges were in 2008 and 2009.

There are a number of specific individuals who deserve mention for the important roles they have played both with the conference and this publication. First is my colleague, Andy Wood, who prepared proposals for funding, identifying conference topics and themes, and helped organize the conference. Andy also assumed leadership responsibilities when I was a Fulbright professor in Kazakhstan in fall semester 2007. He is a good and valuable colleague. Second is Lori Tyndall, the department's business officer; she helped organize many tasks both before and after the conference, including meals, accommodations, travel arrangements, and reimbursements. She was a tireless, cheerful and invaluable member of the conference team. Third, I want to acknowledge the financial support provided by various University of Kentucky offices and departments; these include very generous contributions from the Office of the Provost and Dr. Kumble Subbaswamy; the Office of the Vice President for Research, Dr. Jim Tracy; and the following colleges and deans (in alphabetical order): Arts and Sciences (former Dean Steve Hoch and Associate Dean Leonidas Bachas), Business and Economics (Dean Devanathan Sudharshan), Engineering (Tom Lester), the Graduate School (Jeanine Blackwell), and Public Health (Steve Wyatt). We also received very generous support from the Center for Applied Energy Research and Director Rodney Andrews. Dr. Evelyn Knight, Director of the Appalachian Center, also provided financial assistance. And I want to thank Dr. Douglas Richardson, Executive Director of the Association of American Geographers and Ms. Mary Lynne Bird, Executive Director of the American Geographical Society for publicizing the conference to their members and constituents.

From the start the Department of Geography was supportive of the conference. I am grateful to Karl Raitz, previous chair, and Sue Roberts, current chair, for their enthusiasm and financial support. Richard Gilbreath, Director of the Cartography Laboratory, provided assistance in many ways: preparing the program, designing the creative coffee mug we gave all participants, and preparing last minute maps for some authors. The quality of Dick's work is always outstanding and our department is richer because of his many contributions to faculty research. Finally, I want to 
thank Boyd Shearer for designing the conference poster and Jeff Levy and Raegan Wilson for also assisting with some last minute tasks.

My task immediately following the conference was to prepare a volume for publication. I approached Springer because it is widely recognized as the leading international publisher in science and technology fields and because it published the AAG centennial volume on geography and technology mentioned above. My contacts at Springer, Evelien Bakker and Bernadette Deelen-Mans, expressed a keen interest in this topic the first time I suggested it and they remained constant sources of support as I patiently waited for last minute authors to come through. I very much appreciate the freedom Evelien gave me to identify authors and topics following the July conference, realizing that an international and interdisciplinary volume of this topic really required some additional efforts. A testimony to the international and multidisciplinary dimension of this project is documented by the several hundred professional and scientific journals cited in chapter bibliographies.

The person who helped prepare all manuscripts for Springer was Donna Gilbreath, who has assisted me in previous editorial tasks. She is a very competent, trusted, and reliable professional who enjoys the many major and minor tasks that go with preparing book length manuscripts for a publisher; these include formatting manuscripts, inserting graphics and tables correctly, checking bibliographic entries, and working with authors. I also owe megathanks to Lydia Shinoj who, from half a world away from Lexington, patiently and cheerfully worked with authors on last minute citations, graphics, and phrasing. She is a professional proof-reader and copy-editor in the truest sense and another quality member of the Springer publication team.

This volume includes many who presented papers at the University of Kentucky conference, but also others who were unable to attend because of scheduling conflicts. And there are other chapters written by friends and friends of friends. Some chapters are written by individuals who have made a career of studying one or more megaproject; others are written by junior or senior scholars who welcomed the opportunity to conduct research on a new topic. What is very gratifying is that almost all of those who agreed to contribute chapters provided one. I want to thank all the nearly 200 individual authors who contributed original chapters to the volume; the list includes graduate students and senior scholars, 51 women, and scholars from 28 different countries. Projects are discussed in more than forty countries. Many authors have been friends for life; others became good "virtual" friends as a result of many email exchanges.

I also want to acknowledge those who suggested contributors. Four who deserve extra thanks are Richard Cathcart, Virginie Mamadouh, Jan Monk, and Herman van der Wusten. Others are (in alphabetical order): Stuart Aitken, Harri Andersson, Holly Barcus, Andy Bond, Kathy Braden, Anne Buttimer, Jean Comaroff, Eric Clark, Paul Claval, Harm de Blij, Alex Diener, Ron Eller, Patricia Ehrkamp, Bent Flyvberg, Brian Godfrey, Susan Hanson, Stuart Harris, Andre Horn, Graeme Hugo, John Jakle, P. P. Karan, Aharon Kellerman, Vladimir Kolossov, Evelyn Knight, David Lanegran, Alan Lew, Markku Löytönen, Ashley Lucas, Elizabeth Lunstrum, Lily Kong, Ken Martis, Julian Minghi, Ed Malecki, Peter Muller, Alex Murphy, 
Tad Mutersbaugh, David Newman, Susan Parnell, Sangkom Pumipuntu, Karl Raitz, Marty Reuss, Curt Roseman, Gerry Rushton, Sue Roberts, Michael Samers, Rich Schein, Seven Scott, Anna Secor, Jeff Steller, Hal Simon, Devanathan Sudharshan, Markku Tykkyläinen, Ian Warrington, Jerry Webster, Mary White, Tom Wilbanks, Jack Williams, Julie Winkler, Antoinette WinklerPrins, Pentti Yli-Jokipii, Don Zeigler, and Matt Zook.

I also want to thank artist Adam White for permission to use a much reduced version of his "Children's Games" for the cover. When I saw it at the Royal Dublin Society's winter show in November 2009. I knew immediately that I would like to use it. He is a most gracious artist who weaves together technology and environment, a central theme of this volume.

I am pleased with those who contributed to this volume as it is truly an international and interdisciplinary effort. There authors include physicists and planetary scientists, anthropologists and economists, architects and historians, Internet and Google Earth specialists, environmental scientists and civil engineers, and those who study social justice, environmental risk, and community restructuring. Most authors are geographers and here are many who have different backgrounds and interests; some have strong regional and nature/society interests, others have major research interests in critical social theory and physical geography, and still others have a strong applied focus to their research. As I read and reread these chapters I was very pleased with the common ground that exists among the many contributors and contributions, whether they are writing about large scale dams, transportation projects, tourism developments or social engineering. Even those contributions dealing with GIS and the Internet, climate modeling, reforestation, megaenergy alternatives, and planetary engineering illustrate the contributions to understanding megaprojects that come from those with different scientific, technical, philosophical, and regional expertise.

I hope that the reader will find much in this volume that is of interest for future research. There is clearly much more work that might be, could be (and probably should be) conducted on the impacts of megaengineering projects at all scales and in all major world regions. If this collection stimulates such inquiry, it will have served its purpose.

Finally, I want to thank my wife, Natasha, for her interest and support throughout this project. She was a member of Ken Martis's field trip to the West Virginia coal fields where she witnessed Appalachian megaengineering impacts firsthand, she faithfully attended the conference in 2008, and survived the fall 2007 Fulbright experience in Semipalatinsk, Kazakhstan. I am very grateful for her affection and constant companionship. 



\section{Contents}

\section{Volume 1}

Part I Introduction

1 Introduction to Megaengineering: The Concept and a Research Frontier .

Stanley D. Brunn and Andrew Wood

2 Building the Next Seven Wonders: The Landscape

Rhetoric of Large Engineering Projects . . . . . . . . . . . . . . 13

Ben Marsh and Janet Jones

Part II GIS, ICTs and K-Economies

3 Information Technology as Megaengineering:

The Impact of GIS . . . . . . . . . . . . . . . . . . . . .

Michael F. Goodchild

4 Google and the Internet: A Mega-Project Nesting Within

Another Mega-Project . . . . . . . . . . . . . . . . . .

Maria Paradiso

5 Cloud Collaboration: Peer-Production

and the Engineering of the internet . . . . . . . . . . . . . . . 67

Mark Graham

6 Engineering Community and Place: Facebook

as Megaengineering

Michael Longan and Darren Purcell

7 Real-Time National Stability Engineering: Mapping

the 2009 Afghan Election

Tom Buckley, Sean Gorman, Laurie Schintler,

and Rajendra Kulkarni

8 Engineering Time and Space with the Global Fiber

Optics Industry . . . . . . . . . . . . . . . . . . . . . . . 115

Barney Warf 
9 The Internet in Three Finnish Cities: Accessing

Global Networks

Tommi Inkinen

10 ICTs and Activities on the Move? People's Use of Time

While Traveling by Public Transportation . . . . . . . . . . . . . 145

Bertil Vilhelmson, Eva Thulin, and Daniel Fahlén

11 Assembling Video Game Worlds . . . . . . . . . . . . . . . . . . 155

Ian Graham Ronald Shaw

12 GPS Collars in Studies of Cattle Movement: Cases

of Northeast Namibia and North Finland

Katja Polojärvi, Alfred Colpaert, Kenneth Matengu,

and Jouko Kumpula

13 Engineering Cattle for Dairy Development in Rural India

Pratyusha Basu

14 Social Responses to Crop Biotechnology: Bt Cotton

Cultivation in Gujarat, India . . . . . . . . . . . . . . . . 217

Esha Shah

Part III Agriculture, Fishing and Mining Projects

15 Turning the Soviet Union into Iowa: The Virgin Lands

Program in the Soviet Union . . . . . . . . . . . . . . . . . . . . 237

William C. Rowe

16 The Megaengineering of Ocean Fisheries: A Century

of Expansion and Rapidly Closing Frontiers . . . . . . . . . . . 257

Maarten Bavinck

17 Impacts of Up-Coming Deep-Sea Mining . . . . . . . . . . . . . 275

Tetsuo Yamazaki

18 When Megaengineering Disturbs Ram:

The Sethusamudram Ship Canal Project

Michiel van Dijk and Virginie Mamadouh

19 Deep Drilling: Tunnel Spaces as Gender Spaces . . . . . . . . . . 311

Elisabeth Joris

20 The Megaproject of Mining: A Feminist Critique . . . . . . . . . . 329

Kuntala Lahiri-Dutt

21 The Richest Hole on Earth? Nature, Labor and the Politics of Metabolism at the Bingham Canyon

Copper Mine .

Jody Emel and Matthew T. Huber 
22 When Boom Goes Bust: Ruins, Crisis and Security in Megaengineering Diamond Mining in Angola

Filipe Calvão

23 Ecclesial Opposition to Nonferrous Metals Mining in Guatemala and the Philippines: Neoliberalism

Encounters the Church of the Poor . . . . . . . . . . . . . . . . . 383

William N. Holden and R. Daniel Jacobson

24 Character and Scale of Environmental Disturbances

Resulting from Mining in the Kursk Magnetic Anomaly . . . . . 413

Alina Nekrich

\section{Part IV Energy and Industrial Projects}

25 Engineering and Re-engineering Earth: Industrialized

Harvesting of Ireland's Peatlands and its Aftermath . . . . . . . 429

Proinnsias Breathnach

26 Energy-Hungry Europe: Development Projects in South-Central Europe . . . . . . . . . . . . . . . . . . . . . . 447

Anton Gosar

27 The Next Generation of Energy Landscapes . . . . . . . . . . . . 461 Martin J. Pasqualetti

28 The Repercussions of Being Addicted to Oil: Geospatial

Modeling of Supply Shocks . . . . . . . . . . . . . . . . . . . . . 483

Laurie Schintler, Rajendra Kulkarni, Tom Buckley,

Emily Sciarillo, and Sean Gorman

29 Global Motor Vehicle Assembly: Nationalism,

Economics, and Rationale . . . . . . . . . . . . . . . . . . . . . . 497

Craig S. Campbell

30 Potentials and Employment Impacts of Advanced

Energy Production from Forest Residues in Sparsely

Populated Areas

Olli Lehtonen and Markku Tykkyläinen

31 Megaproject: A 4-Decade Perspective of the Gulf

Development Model

Michael C. Ewers and Edward J. Malecki

\section{Part V Transportation Projects}

32 “America's New Design for Living:" The Interstate

Highway System and the Spatial Transformation

of the U.S.

Joe Weber 
33 The Transamazon Highway: Past, Present, Future . . . . . . . . 569 Robert Walker, Stephen Perz, Eugenio Arima, and Cynthia Simmons

34 Megaprojects in India: Environmental and Land Acquisition Issues in the Road Sector . . . . . . . . . . . . . . . 601 G. Raghuram, Samantha Bastian, and Satyam Shivam Sundaram

35 Shifting Sands: The Trans-Saharan Railway . . . . . . . . . . 617 Mike Heffernan

36 Will New Mobilities Beget New (Im)Mobilities? Prospects for Change Resulting from Mongolia's Trans-State Highway Alexander C. Diener

37 "America's Glory Road" ... On Ice: Permafrost and the Development of the Alcan Highway, 1942-1943 . . . . . 643 Frederick E. Nelson

38 "We Shall Dress You in a Robe of Cement and Concrete:" How Discourse Concerning Megaengineering Projects Has Been Changing in Israel . . . . . . . . . . . . . . . . . . . . 663 Izhak Schnell and Anda Rosenberg

39 Built in a Field of Dreams? Spatial Engineering and Political Symbolism of South Africa's Rapid Rail Link Development, Gautrain ．. . . . . . . . . . . . . . . . . . . 683 Ronnie Donaldson and Janis van der Westhuizen

40 Manufacturing Consent for Engineering Earth: Social Dynamics in Boston's Big Dig James P. McCarthy and Kate Driscoll Derickson

41 Impacts of The "Marmaray" Project (Bosphorus Tube Crossing, Tunnels and Stations) on Transportation and Urban Environment in Istanbul . . . . . . . . . . . . . . 715 Recep Efe and Isa Cürebal

42 Scandinavian Links: Mega Bridges Linking the Scandinavian Peninsula to the European Continent Christian Wichmann Matthiessen and Richard D. Knowles

43 The Qinghai-Tibetan Railroad: Innovative Construction on Warm Permafrost in a Low-Latitude, High-Elevation Region 


\section{Volume 2}

Part VI Construction Companies and Corporation Strategies

44 A Network Perspective on Mega-Engineering Projects . . . . . . 769 Ajay Mehra, Daniel J. Brass, Stephen P. Borgatti, and Giuseppe (Joe) Labianca

45 Bechtel: The Global Corporation . . . . . . . . . . . . . . . . . . 783 Jason Henderson

46 Chinese Construction Industry: Governance, Procurement and Culture . . . . . . . . . . . . . . . . . . . . . 803 Jian Zuo, George Zillante, and Zhen-Yu Zhao

47 An Overview of the Gulf Countries' Construction Industry . . 819 Alpana Sivam, Sadasivam Karuppannan, and Kamalesh Singh

48 Exploring the Role of Governance in Sustainable Franchised Distribution Channels . . . . . . . . . . . . . . . . . 839 Robert Dahlstrom, Arne Nygaard, and Emily Plant

\section{Part VII Megafacilities, Designs and Architecture}

49 Intermodal Terminals, Mega Ports and Mega Logistics . . . . . 851 Jean-Paul Rodrigue

50 Mega-Airports: The Political, Economic, and Environmental Implications of the World's Expanding Air Transportation Gateways . . . . . . . . . . . . . 867 John T. Bowen and Julie L. Cidell

51 University as Megaengineering Project . . . . . . . . . . . . . . 889 Judith A. Martin

52 Creating a New Heaven and a New Earth: Megachurches and the Reengineering of America's Spiritual Soil Scott Thumma and Elizabeth J. Leppman

53 Mega-Engineering Projects in Russia: Examples from Moscow and St. Petersburg

Mikhail S. Blinnikov and Megan L. Dixon

54 Engineering New Geographies with the Burj Dubai Benjamin Smith

55 Floating Cities . . . . . . . . . . . . . . . . . . . . . . . . . . . 967 Alexander A. Bolonkin

56 Planning and Implementing Capital Cities - Lessons from the Past and Prospects for Intelligent Development in the Future: The Case of Korea . . . . . . . . . . . . . . . . . . 985 Kenneth E. Corey 
57 Astana, Kazakhstan: Megadream, Megacity, Megadestiny? . . . 1001 Leon Yacher

58 Myanmar's New Capital City of Naypyidaw _ . . . . . . . . . . 1021 Dulyapak Preecharushh

59 Event Engineering: Urban Planning for Olympics and World's Fairs . . . . . . . . . . . . . . . . . . . . . . . . 1045 Mark I. Wilson

60 Sustainable City Regions: Mega-Projects in Balance with the Earth's Carrying Capacity . . . . . . . . . . . . . . . . 1057 Richard S. Levine, Michael T. Hughes, and Casey Ryan Mather

61 Edge Cities in the Era of Megaprojects . . . . . . . . . . . . . . 1071 Selima Sultana

62 Engineering and the Architecture of Economic Recovery: TARP, the New Deal, and the Evolving Landscapes of Crisis . . . . . . . . . . . . . . . . . . . . . . . . . . . . . . . . . 1089 Andrew Boulton

Part VIII Tourism, Recreation and Amenity Landscapes

63 Engineering Singapore as a City-State and Tourism Destination Joan C. Henderson

64 Val d'Europe: A Mega Urban Project Partnered by Walt Disney Company and the French State . . . . . . . . . . . . . . . 1127 Anne-Marie d'Hauteserre

65 Dredging Paradise: The Making of San Diego's Mission Bay Aquatic Park Larry R. Ford

66 Earth as a Medium: The Art and Engineering of Golf Course Construction

John Strawn, Jim Barger, and J. Drew Rogers

67 Engineering Metaphorical Landscapes and the Development of Zoos: The Toronto Case Study Paul Harpley

68 An Uncomfortable Fit? Transfrontier Parks as MegaProjects

Elizabeth Lunstrum

69 Dams, Casinos and Concessions: Chinese Megaprojects in Laos and Cambodia .

Chris Lyttleton and Pál Nyíri 
70 Engineering Paradise: Marketing the Dominican

Republic's Last Frontier . . . . . . . . . . . . . . . . . . . . . . . 1267

Joseph L. Scarpaci, Korine N. Kolivras, and William Galloway

71 Perfecting and Recreating Nature on the Upper

Mississippi River . . . . . . . . . . . . . . . . . . . . 1283

John O. Anfinson

72 The Bluegrass of Kentucky: An Engineered Image

of a Gracious Life . . . . . . . . . . . . . . . . . . . . . . . . . . 1297

Thomas J. Nieman and Zina R. Merkin

73 Constructing Thoroughbred Breeding Landscapes:

Manufactured Idylls in the Upper Hunter Region

of Australia . . . . . . . . . . . . . . . . . . . . . . . . . . . . . . 1323

Phil McManus, Glenn Albrecht, and Raewyn Graham

\section{Part IX Reconstructing and Restoring Nature}

74 The Earth Restoration Project: An Overview . . . . . . . . . . . 1343

Jeffrey Gritzner, Georgia Milan, and Leonard Berry

75 Huge Yields of Green Belts? Mega and Micro Plantation

Forestry Cases from Indonesia, Ghana and Zimbabwe . . . . . . 1353

Tapani Tyynelä

76 Historic Land Use and Social Policy Affecting

Large-Scale Changes in Forest Cover in the Midwest

United States . . . . . . . . . . . . . . . . . . . . . . . . . . . . . . . 1369

Mikaela Schmitt-Harsh, Sean P. Sweeney, and Tom P. Evans

77 The Historical Decrease of Soil Erosion in the Eastern

United States - The Role of Geography and Engineering . . . . . 1383

Stanley W. Trimble

78 Re-Making America: Soil Mechanics, Earth Moving,

Highways, and Dams . . . . . . . . . . . . . . . . . . . . . . . . 1395

Peter J. Hugill

79 Engineering the Emirates: The Evolution of a New

Environment . . . . . . . . . . . . . . . . . . . . . . . . 1409

Pernilla Ouis

80 Land Marks in the Cure of Madness: The Shaping of 19th Century Asylum Sites in Melbourne, Australia . . . . . . 1425

Anne Bourke

81 Sea Art: The Mediterranean Sea Terrace Proposal . . . . . . . . 1441

Nicola M. Pugno, Richard B. Cathcart, and Alexander Bolonkin 
Part X River Diversion and Coastal Reclamation Projects

82 The U.S. Army Corps of Engineers and the Mississippi River Cutoff Plan

Damon Manders

83 The Impacts of Megahydraulic Engineering Projects from a Dutch Perspective . . . . . . . . . . . . . . . . . . . . . . 1465 Guus J. Borger, Sjoerd J. Kluiving, and Adriaan M.J. De Kraker

84 Dutch Coastal Engineering Projects: Past Success and Future Challenges . . . . . . . . . . . . . . . . . . . . . . . . 1481 Robert Hoeksema

85 Moving the River? China's South-North Water Transfer Project . . . . . . . . . . . . . . . . . . . . . . . . . . . 1499 Darrin Magee

86 The Siberian Water Transfer Scheme . . . . . . . . . . . . 1515 Philip Micklin

87 Freshwater Supplies Necklace Super-Project: Floating Bags and Rolling Freshwater Tires Facilitating Future India-China-Bangladesh Life Necessities Trade . . . . . . . . . 1531 Richard B. Cathcart

88 Aral Sea Partial Refilling Macroproject . . . . . . . . . . . . . . 1541 Richard B. Cathcart and Viorel Badescu

89 Geo-Engineering South Australia: The Case of Lake Eyre . . . . 1549 Viorel Badescu, Richard B. Cathcart, Marius Paulescu, Paul Gravila, and Alexander A. Bolonkin

\section{Part XI Dams}

90 Mega-Hydroelectric Power Generation on the Yangtze

River: The Three Gorges Dam . . . . . . . . . . . . . . . . . . . 1569 Stuart A. Harris

\section{Volume 3}

91 Demographic Impacts of the Three Gorges Dam . . . . . . . . . 1583 Yan Tan and Graeme Hugo

92 Water Worth Gold: The Itaipú Hydroelectric Project … . . . 1599 Melissa H. Birch and Nicolas Quintana Ashwell

93 Megadams for Irrigation in Nigeria: Nature, Dimensions, and Geographies of Impacts Adamu I. Tanko 
94 Ebbs and Flows: Megaproject Politics on the Mekong . . . . . . 1633

Philip Hirsch and Katherine Wilson

95 Beyond Mega on a Mega Continent: Grand Inga

on Central Africa's Congo River . . . . . . . . . . . . . . . . . . 1651

Kate B. Showers

Part XII Military, Security, and Risk Landscapes

96 America's Military Footprint: Landscapes and Built

Environments within the Continental U.S. . . . . . . . . . . . . . 1683

William W. Doe III and Eugene J. Palka

97 Constructing the Border Wall - The Social

and Environmental Impacts of Border:

Mexico-U.S. Border Policy ． . . . . . . . . . . . . . . . . . . . . 1701

Lauren Martin

98 The Engineering of Detentional Landscapes: Australia's

Asylum Seeker Island Prisons . . . . . . . . . . . . . . . . . . . . 1723

Nancy Hudson-Rodd

99 “Alcatraz in the Sky": Engineering Exile in a Virginia

(USA) Prison . . . . . . . . . . . . . . . . . . . . . . . . . . . . . 1749

Matthew L. Mitchelson

100 An Environmental History of the French Nuclear

Complex at La Hague . . . . . . . . . . . . . . . . . . . . . . . . 1765

Laurent Bocéno

101 Fifty Years of Soviet Nuclear Testing in Semipalatinsk,

Kazakstan: Juxtaposed Worlds of Blasts and Silences,

Security and Risks, Denials and Memory . . . . . . . . . . . . . 1789

Stanley D. Brunn

Part XIII Socially Engineered Landscapes

102 Florida's Planned Retirement Communities: Marketing

Age, Religion, Ethnicity and Lifestyle . . . . . . . . . . . . . . . 1821

Ira M. Sheskin

103 Re-engineering the Urban Landscape: Land Use

Reconfiguration and the Morphological Transformation

of Shrinking Industrial Cities . . . . . . . . . . . . . . . . 1855

Alan Mallach

104 Wiring the Countryside: Rural Electrification in Ireland … . 1885 Patrick J. Duffy

105 When a New Deal is Actually an Old Deal: The Role of TVA in Engineering a Jim Crow Racialized Landscape

Derek H. Alderman and Robert N. Brown 
106 A Double-Edged Sword: Social Control in Appalachian Company Towns . . . . . . . . . . . . . . . . . . . . . . . . . . . 1917

Thomas E. Wagner and Phillip J. Obermiller

107 Social Engineering: Creating and Now Undoing Apartheid's Structures

Vernon A. Domingo

108 Engineering Socialism: A History of Village Relocations in Chukotka, Russia

Tobias Holzlehner

109 The State of Deseret: The Creation of the Mormon

Landscape in the Western U.S.

Samuel M. Otterstrom and Richard H. Jackson

110 Subversive Engineering: Building Names in Singapore . . . . . . 1997 Peter K.W. Tan

111 Empire, Names and Renaming: The Case of Nagorno

Karabakh . . . . . . . . . . . . . . . . . . . . . . . . . 2013

Benjamin D. Foster

112 Reconstructing Post-Conflict Human Landscapes:

The Land Administration Domain Model . . . . . . . . . . . . . 2031

Douglas E. Batson

\section{Part XIV Political Organization of Space}

113 Zoning as a Form of Social Engineering

Bobby M. Wilson and Seth Appiah-Opoku

114 Engineering Borders and Border Landscapes:

The Schengen Regime and the EU's New Internal and External Boundaries in Central-Eastern Europe . . . . . . . 2067 Milan Bufon

115 Engineered Healing and the Northern Ireland Question:

Collaboration Across an Increasingly Invisible Border . . . . . . 2089

Caroline Creamer, John Driscoll, Neale Blair, and Brendan Bartley

116 Liquid Urbanity: Re-engineering the City in a Post-Terrestrial World

Philip E. Steinberg

117 Living on the Grid: The U.S. Rectangular Public Land Survey System and the Engineering of the American

Landscape

Gerald R. Webster and Jonathan Leib 
118 Traces of Power: Europe's Impact on the Political

Organization of the Globe . . . . . . . . . . . . . . . . . . . . . . 2139

Corey Johnson and George W. White

119 Air and Space Demarcation . . . . . . . . . . . . . . . . . . . . . 2159

Alexandra Harris and Ray Harris

Part XV Earth and Planetary Engineering

120 A Perspective on Weather Modification: Planned and Inadvertent $\ldots \ldots \ldots$

Nancy Westcott

121 Climate Change, Climate Models and Geoengineering the Earth . . . . . . . . . . . . . . . . . . . . . . . . . 2185 Jay S. Hobgood

122 Olivine Hills: Mineral Water Against Climate Change . . . . . . 2201 Roelof D. Schuiling and Elke Praagman

123 Demise of the Geomagnetic Field: An Opportunity for Mega-Engineers to Save Humanity . . . . . . . . . . . . . . . 2207 J. Marvin Herndon

124 Terraforming Mars: A Review of Concepts . . . . . . . . . . . . 2217 Martyn J. Fogg

125 Planetary Ecosynthesis on Mars and Geo-Engineering on Earth: Can We? Should We? Will We? . . . . . . . . . . . . . 2227 Christopher P. McKay

126 Global Warming and the Specter of Geoengineering:

Ecological Apocalypse, Modernist Hubris, and

Scientific-Technological Salvation in Kim Stanley

Robinson's Global Warming Trilogy . . . . . . . . . . . . . . . . 2233

Ernest J. Yanarella and Christopher Rice 



\section{Contributors}

Glenn Albrecht School of Sustainability; Institute of Sustainability and Technology Policy, Murdoch University, 6150 Perth, WA, Australia, g.albrecht@murdoch.edu.au

Derek H. Alderman Department of Geography, East Carolina University, Greenville, NC 27858, USA, aldermand@ecu.edu

John O. Anfinson Mississippi National River and Recreation Area, National Park Service, St. Paul, MN 55101, USA, john_anfinson@nps.gov

Seth Appiah-Opoku Department of Geography, University of Alabama, Tuscaloosa, AL 35487, USA, sappiah@ bama.ua.edu

Eugenio Arima Environmental Studies, Hobart and William Smith Colleges, Geneva, NY 14456, USA, arima@hws.edu

Viorel Badescu Candida Oancea Institute, Polytechnic University of Bucharest, Bucharest, Romania, badescu@ theta.termo.pub.ro

Jim Barger Landscapes Unlimited, Lincoln, NE 68512, USA, Jim@landscapesunlimited.com

Brendan Bartley International Centre for Local and Regional Development, c/o National University of Ireland, Maynooth, Co. Kildare, Ireland, Brendan.Bartley@nuim.ie

Samantha Bastian Public Systems Group, Indian Institute of Management-Ahmedabad, Ahmedabad, Gujarat, India, samantha@iimahd.ernet.in

Pratyusha Basu Department of Geography, University of South Florida, Tampa, FL 33620, USA, pbasu@usf.edu

Douglas E. Batson Political Geography Division, National Geospatial-Intelligence Agency, Washington, DC, USA, douglas.e.batson@nga.mil

Maarten Bavinck Department of Human Geography, Planning and International Development; Centre for Maritime Research, University of Amsterdam, Amsterdam, The Netherlands, j.m.bavinck@uva.nl 
Leonard Berry Florida Center for Environmental Studies, Florida Atlantic University, Jupiter, FL 33458, USA, berry@ fau.edu

Melissa H. Birch Center for International Business Education and Research (CIBER), University of Kansas, Lawrence, KS 66045, USA, mhbirch@ku.edu

Neale Blair School of the Built Environment, University of Ulster, Newtonabbey, Co. Antrim BT37 0QB, Northern Ireland, N.Blair@ulster.ac.uk

Mikhail S. Blinnikov Department of Geography, St. Cloud State University, St. Cloud, MN 56301, USA, msblinnikov@ stcloudstate.edu

Laurent Bocéno Department of Sociology, Center for the Study and Research on Risks and Vulnerabilities, University of Caen-Lower Normandy, Caen, France, laurent.boceno@unicaen.fr

Alexander A. Bolonkin C \& R, Brooklyn, NY 11229, USA, abolonkin@juno.com

Stephen P. Borgatti LINKS, International Center for Research on Social Networks in Business, Gatton College of Business and Economics, University of Kentucky, Lexington, KY 40506, USA, steve.borgatti@gmail.com

Guus J. Borger Faculty of Earth and Life Sciences, Institute for Geo and Bioarchaeology, VU University of Amsterdam, Amsterdam, The Netherlands, g.j.borger@uva.nl

Andrew Boulton Department of Geography, University of Kentucky, Lexington, KY 40506, USA, andrew.boulton@gmail.com

Anne Bourke Faculty of Architecture, Building and Planning, University of Melbourne, Melbourne, VIC, Australia, a.bourke2@pgrad.unimelb.edu.au

John T. Bowen Department of Geography, Central Washington University, Ellensburg, WA 98626, USA, bowenjo@cwu.edu

Daniel J. Brass LINKS, International Center for Research on Social Networks in Business, Gatton College of Business and Economics, University of Kentucky, Lexington, KY 40506, USA, dbrass@email.uky.edu

Proinnsias Breathnach Department of Geography \& National Institute for Regional and Spatial Analysis, National University of Ireland, Maynooth, Co. Kildare, Ireland, Proinnsias.Breathnach@ nuim.ie

Robert N. Brown Department of Geography \& Planning, Appalachian State University, Boone, NC 28608, USA, brownrn@app.state

Stanley D. Brunn Department of Geography, University of Kentucky, Lexington, KY 40506, USA, brunn@uky.edu

Tom Buckley FortiusOne, Inc., Arlington, VA 22201, USA, topm@fortiusone.com Milan Bufon Department of Geography, Faculty of Humanities, University of Primorska, Koper, Slovenia, milan.bufon@upr.si 
Filipe Calvão Department of Anthropology, University of Chicago, Chicago, IL 60637, USA, fcalvao@uchicago.edu

Craig S. Campbell Department of Geography, Youngstown State University, Youngstown, OH 44555, USA, cstevencampbell@ sbcglobal.net

Richard B. Cathcart Geographos, Burbank, CA 91506, USA, rbcathcart@gmail.com

Julie L. Cidell Department of Geography, University of Illinois, Urbana, IL, 61801, USA, jcidell@illinois.edu

Alfred Colpaert Department of Geographical and Historical Studies, University of Eastern Finland, Joensuu, Finland, alfred.colpaert@uef.fi

Kenneth E. Corey Department of Geography, Michigan State University, East Lansing, MI 48824, USA, kenneth.corey@ssc.msu.edu

Caroline Creamer National Institute for Research and Spatial Analysis (NIRSA), National University of Ireland, Maynooth, Co. Kildare, Ireland; International Centre for Local and Regional Development (ICLRD), Armagh, Northern Ireland, Caroline.Creamer@nuim.ie

Isa Cürebal Department of Geography, Balikesir University, Balikesir 10145, Turkey, curebal@balikesir.edu.tr

Anne-Marie d'Hauteserre Department of Geography, University of Waikato, Hamilton, New Zealand, adhautes@waikato.ac.nz

Robert Dahlstrom Gatton College of Business and Economics, University of Kentucky, Lexington, KY 40506, USA, dahlstrom@uky.edu

Adriaan M.J. De Kraker Institute for Geo and Bioarchaeology, VU University of Amsterdam, Amsterdam, The Netherlands, adriaan.de.kraker@falw.vu.nl

Kate Driscoll Derickson Department of Geography, Penn State University, University Park, PA 16802, USA, kderickson@psu.edu

Alexander C. Diener Senior Scholar in Eurasian Studies, IERES Elliott School of International Affairs, George Washington University, USA, alexander.diener@pepperdine.edu

Megan L. Dixon Departments of English and Geology, College of Idaho, Caldwell, ID 83605, USA, mldixon@collegeofidaho.edu

William W. Doe III Warner College of Natural Resources, Colorado State University, Ft. Collins, CO 80523, USA, william.doe@ colostate.edu

Vernon A. Domingo Department of Geography, Bridgewater State University, Bridgewater, MA 02325, USA, vdomingo@bridgew.edu 
Ronnie Donaldson Department of Geography and Environmental Studies, University of Stellenbosch, Stellenbosch, Western Cape Matieland 7602, South Africa, rdonaldson@sun.ac.za

John Driscoll International Centre for Local and Regional Development (ICLRD), 2235 Massachusetts Avenue, Second Floor, Cambridge, MA 02140, driscoll@iclrd.org

Patrick J. Duffy Department of Geography, National University of Ireland, Maynooth, Co. Kildare, Ireland, Patrick.duffy@ nuim.ie

Recep Efe Department of Geography, Balikesir University, Balikesir 10145, Turkey, recepefe@hotmail.com,refe@balikesir.edu.tr

Jody Emel Department of Geography, Clark University, Worcester, MA 01610, USA, jemel@clarku.edu

Tom P. Evans Department of Geography, Center for the Study of Institutions, Population, and Environmental Change, Indiana University, Bloomington, IN 47405, USA, evans@indiana.edu

Michael C. Ewers Department of Geography, Texas A\&M University, College Station, TX 77843-3147, USA, mewers@geog.tamu.edu

Daniel Fahlén Department of Human and Economic Geography, School of Business, Economics and Law, University of Gothenburg, SE 405 30, Gothenburg, Sweden, Daniel.Fahlen@geography.gu.se

Martyn J. Fogg Probability Research Group, London SE19 1UY, UK, mfogg@globalnet.co.uk

Larry R. Ford Department of Geography, San Diego State University, San Diego, CA 92182, USA, (contact saitken@mail.sdsu.edu)

Benjamin D. Foster U.S. Board on Geographic Names, Foreign Names Committee, Washington, DC, USA, fosterbd@nga.mil

William Galloway School of Architecture and Urban Studies, Virginia Tech University, Blacksburg, VA 24061, USA, galloway@vt.edu

Michael F. Goodchild Department of Geography, University of California, Santa Barbara, CA 93106, USA, good@geog.ucsb.edu

Sean Gorman FortiusOne, Inc., Arlington, VA 22201, USA, sean@fortiusone.com

Anton Gosar Department of Geography, University of Primorska, Koper/Capodistria, Slovenia, anton.gosar@guest.arnes.si

Mark Graham Oxford Internet Institute, University of Oxford, Oxford, UK, immedium@gmail.com

Raewyn Graham School of Geosciences, University of Sydney, Sydney, Australia,rgra4520@usyd.edu.au 
Paul Gravila Department of Physics, West University of Timisoara, Timisoara, Romania,gravila@physics.uvt.ro

Jeffrey Gritzner Department of Geography, University of Montana, Missoula, MT 59812, USA, jeffrey.gritzner@umontana.edu

Paul Harpley PhD candidate, Department of Geography, York University, Toronto, ON, Canada; Director of the Zephyr Society of Lake Simcoe, Sutton West, ON, Canada; Retired, Manager of Interpretation, Culture and Design Branch, Toronto Zoo, Toronto, ON, Canada, paul@ harpley.ca

Alexandra Harris Department of Geography, University College London, London WC1H 0AP, UK, ray.harris@ucl.ac.uk

Ray Harris Department of Geography, University College London, London, WC1H 0AP, UK, ray.harris@ucl.ac.uk

Stuart A. Harris Department of Geography, University of Calgary, Calgary, AB T2N 1N4, Canada, harriss@ucalgary.ca

Mike Heffernan School of Geography, University of Nottingham, Nottingham NG7 2NR, UK, mike.heffernan@nottingham.ac.uk

Jason Henderson Department of Geography, San Francisco State University, San Francisco, CA 94132, USA, jhenders@sfsu.edu

Joan C. Henderson Nanyang Business School, Nanyang Technological University, Nanyang Avenue, Singapore, ahenderson@ntu.edu.sg

J. Marvin Herndon Transdyne Corporation, San Diego, CA 92131, USA, mherndon@san.rr.com

Philip Hirsch School of Geosciences; Australian Mekong Resource Centre, University of Sydney, Sydney, NSW 2006, Australia, philip.hirsch@usyd.edu.au

Jay S. Hobgood Department of Geography, Ohio State University, Columbus, OH 43210, USA, hobgood.1 @ osu.edu

Robert Hoeksema Engineering Department, Calvin College, Grand Rapids, MI 49546, USA, rhoeksem@ calvin.edu

William N. Holden Department of Geography, University of Calgary, Calgary, AB T2N 1N4, Canada, wnholden@ucalgary.ca

Tobias Holzlehner Department of Anthropology, University of Alaska, Fairbanks, AK 99775, USA, tsholzlehner@alaska.edu

Matthew T. Huber Department of Geography, The Maxwell School of Syracuse University, Syracuse, NY, 13244-1020, USA, mthuber@maxwell.syr.edu

Nancy Hudson-Rodd Honorary Research Fellow, School of Psychology and Social Science, Edith Cowan University, Perth, WA, Australia, n.hudson_rodd@ecu.edu.au 
Michael T. Hughes College of Design, University of Kentucky, Lexington, KY 40506, USA, michaelhughes81@yahoo.com

Peter J. Hugill Department of Geography and Bush School International Affairs Program, Texas A\&M University, College Station, TX 77843, USA, pjhugill@tamu.edu

Graeme Hugo Department of Geography, University of Adelaide, Adelaide, SA, Australia,graeme.hugo@adelaide.edu.au

Tommi Inkinen Department of Geosciences and Geography, University of Helsinki, Helsinki, Finland, tommi.Inkinen@ helsinki.fi

Richard H. Jackson Department of Geography, Brigham Young University, Provo, UT 84602, USA, richard_jackson@byu.edu

R. Daniel Jacobson Department of Geography, University of Calgary, Calgary, AB T2N 1N4, Canada, rjacobso@ucalgary.ca

Corey Johnson Department of Geography, University of North Carolina, Greensboro, NC 27402, USA, cmjohns8@uncg.edu

Janet Jones Department of Classics, Bucknell University, Lewisburg, PA 17837, USA, jjones@bucknell.edu

Elisabeth Joris Historian, Gemeindestrasse 62, CH-8032, Zurich, Switzerland, ejoris@bluewin.ch

Sadasivam Karuppannan Institute for Sustainable Systems and Technologies (ISST), University of South Australia, Adelaide, SA, Australia, sadasivam.karuppannan@unisa.edu.au

Sjoerd J. Kluiving Faculty of Earth and Life Sciences, Institute for Geo and Bioarchaeology, VU University of Amsterdam, Amsterdam, The Netherlands, sjoerd.kluiving@falw.vu.nl

Korine N. Kolivras Department of Geography, Virginia Tech, Blacksburg, VA 24061, USA, korine@vt.edu

Richard D. Knowles Research Institute for the Built and Human Environment, University of Salford, Manchester, UK, r.d.knowles@salford.ac.uk

Rajendra Kulkarni School of Public Policy, George Mason University, Fairfax, VA 22030, USA, rkulkarn@gmu.edu

Jouko Kumpula Reindeer Research Unit, Finnish Game and Fisheries Research Institute, Kaamanen, Finland, jouko.kumpula@rktl.fi

Giuseppe (Joe) Labianca LINKS, International Center for Research on Social Networks in Business, Gatton College of Business and Economics, University of Kentucky, Lexington, KY 40506, USA, joe.labianca@uky.edu 
Kuntala Lahiri-Dutt Research School of Pacific and Asian Affairs, Australian National University, Canberra, ACT, Australia, kuntala.lahiri-dutt@anu.edu.au

Olli Lehtonen Department of Geography, University of Eastern Finland, Joensuu, Finland, olli.lehtonen@uef.fi

Jonathan Leib Department of Political Science and Geography, Old Dominion University, Norfolk, VA 23529, USA, jleib@ odu.edu

Elizabeth J. Leppman Walden University, Lexington, KY 40503, USA, ejleppman@windstream.net

Richard S. Levine College of Design, University of Kentucky, Lexington, KY 40506, USA, rlevine@uky.edu

Michael Longan Department of Geography and Meteorology, Valparaiso University, Valparaiso, IN 46383, USA, mike.longan@valpo.edu

Elizabeth Lunstrum Department of Geography, York University, Toronto, ON M3J 1P3, Canada, lunstrum@yorku.ca

Chris Lyttleton Department of Anthropology, Macquarie University, Sydney, NSW, Australia, chris.lyttleton@mq.edu.au

Darrin Magee Environmental Studies, Hobart and William Smith Colleges, Geneva, NY 14456, USA, magee@ hws.edu

Edward J. Malecki Department of Geography, Ohio State University, Columbus, OH 43210, USA, malecki.4@osu.edu

Alan Mallach Metropolitan Policy Program, The Brookings Institution, Washington, DC 20036, USA, amallach@ comcast.net

Virginie Mamadouh Department of Human Geography, Planning and International Development, University of Amsterdam, Nieuwe Prinsengracht 130, 1018VZ, Amsterdam, The Netherlands, v.d.mamadouh@uva.nl

Damon Manders U.S. Army Corps of Engineers, St. Louis, MO 63103, USA, jon.d.manders@usace.army.mil

Ben Marsh Department of Geography and Program in Environmental Studies, Bucknell University, Lewisburg, PA 17837, USA, marsh@bucknell.edu

Judith A. Martin Department of Geography, University of Minnesota, Minneapolis, MN 55455, USA, jmartin@umn.edu

Lauren Martin Department of Geography, University of Kentucky, Lexington, KY 40506, USA, lauren.martin@uky.edu

Kenneth Matengu Social Sciences Division, Multidisciplinary Research Center, University of Namibia, Windhoek, Namibia, kmatengu@unam.na 
Casey Ryan Mather College of Design, University of Kentucky, Lexington, KY 40506, USA, caseyryanmather@gmail.com

Christian Wichmann Matthiessen Institute of Geography and Geology, University of Copenhagen, 1350 Copenhagen K, Denmark, cwm@geo.ku.dk

James P. McCarthy Department of Geography, Penn State University, University Park, PA 16802, USA, mccarthy@geog.psu.edu

Christopher P. McKay Space Science Division, NASA Ames Research Center, Moffett Field, CA 94035, USA, christopher.mckay@nasa.gov

Phil McManus School of Geosciences, University of Sydney, Sydney, NSW, Australia, phil.mcmanus@sydney.edu.au

Ajay Mehra LINKS, International Center for Research on Social Networks in Business, Gatton College of Business and Economics, University of Kentucky, Lexington, KY 40506, USA, ajaymehra1@gmail.com

Zina R. Merkin Department of Landscape Architecture, University of Kentucky, Lexington, KY 40506, USA, zmerkin@uky.edu

Philip Micklin Department of Geography, Western Michigan University, Kalamazoo, MI 49008, USA, philip.micklin@wmich.edu

Georgia Milan Women's Care Center, St. Patrick Hospital, Missoula, MT 59802, USA,gmilan@saintpatrick.org

Matthew L. Mitchelson Department of Geography, University of Georgia, Athens, GA 30602, USA, mmitchel@uga.edu

Alina Nekrich Institute of Geography, Russian Academy of Sciences, 119017 Moscow, Russia, nekrichalina@yahoo.com

Frederick E. Nelson Department of Geography, University of Delaware, Newark, DE 19716, USA, fnelson@udel.edu

Thomas J. Nieman Landscape Architecture, University of Kentucky, Lexington, KY 40506, USA, tnieman@uky.edu

Arne Nygaard Norwegian School of Management, Centre for Advanced Research in Retailing, Oslo, Norway, arne.nygaard@bi.no

Pál Nyíri Global History from an Anthropological Perspective, Free University of Amsterdam (VU), Amsterdam, The Netherlands, p.nyiri@fsw.vu.nl

Phillip J. Obermiller School of Planning, University of Cincinnati, Cincinnati, OH 45221, USA, solotso@aol.com

Samuel M. Otterstrom Department of Geography, Brigham Young University, Provo, UT 84602, USA, samuel_otterstrom@byu.edu 
Pernilla Ouis Faculty of Health and Society, Malmö University, Malmö, Sweden, pernilla.ouis@mah.se

Eugene J. Palka Department of Geography and Environmental Engineering, U. S. Military Academy, West Point, NY 10996, USA, gene.palka@usma.edu

Maria Paradiso Department of Social Sciences, University of Sannio, Benevento, Italy,paradiso@unisannio.it

Martin J. Pasqualetti School of Geographical Sciences and Urban Planning, Arizona State University, Tempe, AZ 85287, USA, pasqualetti@asu.edu

Marius Paulescu Department of Physics, West University of Timisoara, Timisoara, Romania, marius@physics.uvt.ro

Stephen Perz Department of Sociology, University of Florida, Gainesville, FL 32611, USA, sperz@soc.ufl.edu

Emily Plant University of Montana, Missoula, MT 59812, emily.plant@business.umt.edu

Katja Polojärvi School of Renewable Natural Resources, Oulu University of Applied Sciences, Oulu, Finland, katja.polojarvi@oamk.fi

Elke Praagman Institute of Geosciences, University of Utrecht, Utrecht, The Netherlands, elleri@hotmail.com

Dulyapak Preecharushh Southeast Asian Studies Program, Thammasat University, Bangkok, Thailand, dulyapak08@ hotmail.com

Nicola M. Pugno Department of Structural Engineering and Geotechnics, 10129 Torino, Italy, nicola.pugno@polito.it

Darren Purcell Department of Geography, University of Oklahoma, Norman, OK 73019, USA, profpurcell@gmail.com,dpurcell@ou.edu

Nicolas Quintana Ashwell Department of Economics, University of Illinois, Urbana, IL 61801, USA, quintan2@illinois.edu

G. Raghuram Public Systems Group, Indian Institute of Management-Ahmedabad, Ahmedabad, Gujarat, India, graghu@iimahd.ernet.in

Christopher Rice Department of Political Science, University of Kentucky, Lexington, KY 40506, USA, christopher.rice@uky.edu

Jean-Paul Rodrigue Department of Global Studies \& Geography, Hofstra University, Hempstead, NY 11550, USA, jean-paul.rodrigue@ hofstra.edu

J. Drew Rogers Golf Course Architect, JDR Design Group, Toledo, OH 43617, USA, drogers@bex.net

Anda Rosenberg Department of Geography and Human Environment, Tel Aviv University, Tel Aviv, Israel, anda@012.net.il 
William C. Rowe Department of Geography and Anthropology, Louisiana State University, Baton Rouge, LA 70803, USA, rowe@1su.edu

Joseph L. Scarpaci Independent Scholar, Blacksburg, VA 24060, USA, joescarpaci@gmail.com

Laurie Schintler School of Public Policy, George Mason University, Fairfax, VA 22030, USA, 1schintl@gmu.edu

Mikaela Schmitt-Harsh School of Public and Environmental Affairs, Center for the Study of Institutions, Population, and Environmental Change, Indiana University, Bloomington, IN 47405, USA, schmittm@indiana.edu

Izhak Schnell Department of Geography and Human Environment, Tel Aviv University, Tel Aviv, Israel, schnell@post.tau.ac.il

Roelof D. Schuiling Institute of Geosciences, University of Utrecht, Utrecht, The Netherlands, schuiling@geo.uu.nl

Emily Sciarillo FortiusOne, Inc., Arlington, VA 22201, USA, emily@fortiusone.com

Esha Shah Department of Technology and Society Studies, Faculty of Arts and Social Sciences, University of Maastricht, 6211 SZ, Maastricht, The Netherlands, e.shah@maastrichtuniversity.nl

Ian Graham Ronald Shaw Department of Geography and Development, University of Arizona, Tucson, AZ 85721, USA, ishaw @email.arizona.edu

Ira M. Sheskin Department of Geography and Regional Studies, University of Miami, Coral Gables, FL 33124, USA, isheskin@miami.edu

Kate B. Showers Department of Geography, School of Global Studies, Centre for World Environmental History, University of Sussex, Brighton, BN1 9SJ, UK, kshowers@becon.org

Cynthia Simmons Department of Geography, Michigan State University, East Lansing, MI 48824, USA, simmo108@msu.edu

Kamalesh Singh Structure Department, National Engineering Office (Architects and Consulting Engineers), Ruwi, Sultanate of Oman, kamalesh@omantel.net.om, neoffice@ omantel.net.om

Alpana Sivam Institute for Sustainable Systems and Technologies (ISST), School of Natural and Built Environments, University of South Australia, Adelaide, SA, Australia, alpana.sivam@unisa.edu.au

Benjamin Smith Department of Global and Sociocultural Studies, Florida International University, Miami, FL 33109, USA, bsmith@fiu.edu

Philip E. Steinberg Department of Geography, Florida State University, Tallahassee, FL 32306, USA, psteinberg@fsu.edu 
John Strawn Hill and Forrest, International Golf Course Architects, Portland, OR 97212,USA, john@johnstrawn.com

Selima Sultana Department of Geography, University of North Carolina, Greensboro, NC 27402, USA, s_sultan@uncg.edu

Satyam Shivam Sundaram Public Systems Group, Indian Institute of Management-Ahmedabad, Ahmedabad, Gujarat, India, sss@iimahd.ernet.in

Sean P. Sweeney Center for the Study of Institutions, Population, and Environmental Change, Indiana University, Bloomington, IN 47405, USA, spsweene@indiana.edu

Peter K.W. Tan Department of English Language and Literature, National University of Singapore, 7 Arts Link, Singapore 117570, petertan@nus.edu.sg

Yan Tan National Institute of Labour Studies, Flinders University, Adelaide, SA, Australia, yan.tan@flinders.edu.au

Adamu I. Tanko Department of Geography, Bayero University, Kano, Nigeria, aitanko@gmail.com

Eva Thulin Department of Human and Economic Geography, School of Business, Economics and Law, University of Gothenburg, SE 405 30, Gothenburg, Sweden, Eva.Thulin@geography.gu.se

Scott Thumma Sociology of Religion, Hartford Seminary, Hartford, CT 06105, USA, sthumma@hartsem.edu

Stanley W. Trimble Department of Geography, University of California, Los Angeles, CA 90024, USA, trimble@geog.ucla.edu

Markku Tykkyläinen Department of Geography, University of Eastern Finland, Joensuu, Finland, markku.tykkylainen@uef.fi

Tapani Tyynelä Finnish Forest Research Institute, Kannus, Finland, tapani.tyynela@metla.fi

Janis van der Westhuizen Department of Political Science, University of Stellenbosch, Stellenbosch, Western Cape Matieland 7602, South Africa, jvdw2@sun.ac.za

Michiel van Dijk Department of Human Geography, Planning and International Development, University of Amsterdam, Nieuwe Prinsengracht 130, 1018 VZ, Amsterdam, The Netherlands, m.g.vandijk1@gmail.com

Bertil Vilhelmson Department of Human and Economic Geography, School of Business, Economics and Law, University of Gothenburg, SE 405 30, Gothenburg, Sweden, Bertil.Vilhelmson@geography.gu.se

Thomas E. Wagner School of Planning, University of Cincinnati, Cincinnati, OH 45221, USA, wagnerte@ucmail.uc.edu 
Robert Walker Department of Geography, Michigan State University, East Lansing, MI 48824, USA, rwalker@msu.edu

Barney Warf Department of Geography, University of Kansas, Lawrence, KS 66045, USA, bwarf@ku.edu

Joe Weber Department of Geography, University of Alabama, Tuscaloosa, AL 35487, USA, jweber2@bama.ua.edu

Gerald R. Webster Department of Geography, University of Wyoming, Laramie, WY 82071, USA, gwebste1@uwyo.edu

Nancy Westcott Illinois State Water Survey, Institute of Natural Resource Stability, University of Illinois, Urbana, IL 61801, USA, nan@illinois.edu

George W. White Department of Geography, South Dakota State University, Brookings, SD 57007, USA, george.white@sdstate.edu

Bobby M. Wilson Department of Geography, University of Alabama, Tuscaloosa, AL 35487, USA, bmwilson@as.ua.edu

Katherine Wilson Geography and International Relations, University of Sydney, Sydney, NSW, Australia, kiwi3757@mail.usyd.edu.au

Mark I. Wilson School of Planning, Design and Construction, Michigan State University, East Lansing, MI 48824, USA, wilsonmm@msu.edu

Andrew Wood Department of Geography, University of Kentucky, Lexington, KY 40506, USA, andrew.wood@uky.edu

Leon Yacher Department of Geography, Southern Connecticut State University, New Haven, CT 06515-1355, USA, yacher@ southernct.edu

Tetsuo Yamazaki Osaka Prefecture University, Osaka, Japan, ty26081953@ hotmail.com

Ernest J. Yanarella Department of Political Science, University of Kentucky, Lexington, KY 40506, USA, ejyana@uky.edu

Zhen-Yu Zhao Department of Construction Management, North China Electric Power University, Beijing, China, zhaozhenyuxm@263.net

George Zillante School of Natural and Built Environments, University of South Australia, Adelaide, Australia, george.zillante@unisa.edu.au

Jian Zuo School of Natural and Built Environments, University of South Australia, Adelaide, SA, Australia, jian.zuo@unisa.edu.au 


\section{List of Figures}

$1.1 \quad$ Mapping the impacts of megaengineering projects $\ldots \ldots \ldots$

1.2 Chapters discussing the impacts of megaengineering projects ................... 8

2.1 Traditional 20th century popular presentation of the sole surviving Wonder, The Pyramid of Khufu at Giza, from a vintage postcard . . . . . . . . . . . . . . . . 18

2.2 Location of the Hellenistic Seven Wonders and of the 2007 "New 7 Wonders." The older list (circles) was cosmopolitan within the Hellenistic world of the eastern Mediterranean; the newer list (triangles) delimits popular international travel destinations for European and North American tourists

2.3 The Los Angeles Freeway Interchange, symbol of efficient modern travel - and also of sprawl and profligate energy consumption ..................... 26

2.4 Civic pride of New York incorporated into a U.S. postage stamp, featuring the Manhattan skyline and the gateway symbols of the Statue of Liberty and the Hudson River waterfront

2.5 Skyline of Shanghai, which has thoroughly eclipsed New York in density of skyscrapers. Quintessentially urban landscapes have become more prevalent in Asia than in the Eurocentric world over the last decade . . . . . . . . . . . . 31

$5.1 \quad$ My/our/your time person of the year award . . . . . . . . . 68

5.2 Time and space convergence in various types of large

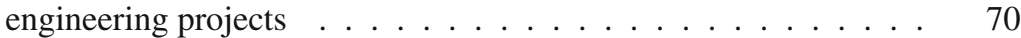

5.3 Avatars in second life . . . . . . . . . . . . . . 72

5.4 The multiple representations of trafalgar square in google maps . 74

5.5 A singular representation of trafalgar square in wikipedia . . . . 74

$5.6 \quad$ Uncle GNU . . . . . . . . . . . . . . . . . . . . . 78

6.1 Change in Internet Development Index (IDI), a measure of the relative infrastructure quality, 2002-2007 . . . . . . 86 
6.2 Percentage of the Population in Selected Countries that Use Facebook . . . . . . . . . . . . . . . . . . . . . . . 91

6.3 Map of the Facebook profile page . . . . . . . . . . . . . 91

6.4 Map of the Facebook home page where the news feed is located . . . . . . . . . . . . . . . . . . . . 92

7.1 Camp Roberts architecture diagram . . . . . . . . . . . . 106

7.2 Afghan elections architecture diagram . . . . . . . . . . . 108

7.3 Afghanistan attacks by district, September 2-8, 2009 . . . . . . . 109

7.4 Change in violence by district, August 11-September 9,

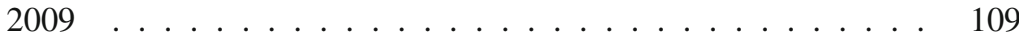

7.5 Total fraud complaints by province for the 2009 Afghanistan presidential election . . . . . . . . . . . . . 110

7.6 Citizen reported election day incidents . . . . . . . . . . . 111

7.7 Benford fraud analysis of Afghanistan election results . . . . . . 112

8.1 Qwest national fiber network . . . . . . . . . . . . . 119

8.2 The World's major fiber optic cables . . . . . . . . . . . . . 123

8.3 The FLAG network . . . . . . . . . . . . . . . . . . 125

8.4 The Africa ONE fiber system . . . . . . . . . . . . . . . 126

8.5 Declining prices of fiber optics services, 2002-2006 . . . . . . 127

10.1 Public transportation network in the survey area-Gothenburg region, Sweden. Transportation lines included in the survey are UddevallaGöteborg, Trollhättan-Göteborg, Borås-Göteborg, and Kinna-Göteborg . . . . . . . . . . . . . . . . . . . . . . . 148

10.2 Average time spent on various activities or using various kinds of equipment by travelers who perceive their trips as "very worthwhile" $(n=60)$. Average trip time $=$ 55 min. Source: Authors' survey, Gothenburg region, Sweden-preliminary findings . . . . . . . . . . . . 152

11.1 Map of countries participating in the World Cyber Games 2009 . 159

12.1 Location of study area, cattle enclosures and tracking data . . . . 175

12.2 Typical livestock enclosure, often called a "kraal." . . . . . . . . 175

12.3 Cattle grazing on the Zambezi/Chobe floodplain . . . . . . . . . 176

12.4 Bull fitted with GPS collar . . . . . . . . . . . . . . . . . 177

12.5 Tracking data from collar no. 9 during July-November $2006 \ldots \ldots \ldots \ldots$. . . . . . . . . . . . . . . 179

12.6 During 2002-2005 altogether 40 female reindeer were tracked by GPS collars in the Oraniemi reindeer herding district, Middle-Lapland . . . . . . . . . . . . . . . . . . . . . 182

12.7 All locations of GPS-tracked female reindeer $(n=29)$ from 1999 to 2002 (10,981 locations) in the Ivalo reindeer herding district and classified into three seasonal periods . . . . . 183

12.8 Ten months GPS-track of a reindeer in the Ivalo district . . . . . 185

13.1 Schematic representation of the Anand model of dairy development 
13.2 Total milk production in India, 1950-2010 (in million tons). (*Figures for 2009-2010 are estimated) . . . . . . . . . . . 197

13.3 Comparison of numbers of cattle and buffaloes, 1982-2003 . . . . 199

13.4 Total milk production from cattle and buffaloes, 2003-2004 (in thousand tons) . . . . . . . . . . . . . 200

13.5 Proportion of total milk production from crossbred cows,

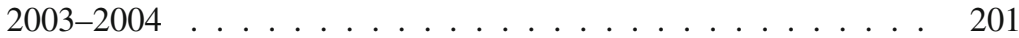

13.6 Crossbred cow in village in Gujarat . . . . . . . . . . . . . . . . 202

13.7 Poster promoting Jersey and Holstein-Friesian crossbred cows as "true friends of farmers" . . . . . . . . . . . . . . . . 203

13.8 Portion of poster promoting artificial insemination of cattle . . . . 204

13.9 Artificial insemination station in village in Madhya Pradesh . . . 205

13.10 Milking crossbred cow in village in Gujarat . . . . . . . . . . . . 208

15.1 Khrushchev visiting the farm of Iowa farmers Roswell and Elizabeth Garst, September 1959 . . . . . . . . . . . 238

15.2 Central Asian agricultural land use map illustrating the major area of the Virgin Lands Project . . . . . . . . . . . . . 245

15.3 Volunteers in the virgin lands . . . . . . . . . . . . . . 247

15.4 Constructing outdoor stoves in the virgin lands . . . . . . . . . 248

15.5 The first furrows in the virgin lands . . . . . . . . . . . . . . 248

15.6 Plowing in the virgin lands . . . . . . . . . . . . . . 249

15.7 Wheat fields in the virgin lands . . . . . . . . . . . . . 250

15.8 Dust storm in Astana . . . . . . . . . . . . . . . . . 252

16.1 World production capture fisheries 1950-2008. (FAO, 2009) ............................ 259

16.2 Trends in U.S. real price indexes for fish and seafood products 1947-2006. (World Bank, 2008) . . . . . . . . . . . 260

16.3 State of world marine fishery resources . . . . . . . . . . . 261

16.4 Exclusive economic zones of the world . . . . . . . . . . . . 262

16.5 Small-scale fishermen in South India . . . . . . . . . . . . . . 265

16.6 Fleets of small industrialized vessels in South India . . . . . . . . 266

16.7 The Atlantic Dawn - the world's largest factory ship . . . . . . . 269

17.1 Issued mining claims for manganese nodules from ISA in CCFZ . 276

17.2 Schematic image of manganese nodule mining system and the environmental impact sources . . . . . . . . . . . . . 277

17.3 Schematic arrangement of JET . . . . . . . . . . . . . . 280

17.4 Disturber track . . . . . . . . . . . . . . . 281

17.5 Outline of scraper tow (left) and the unit configuration

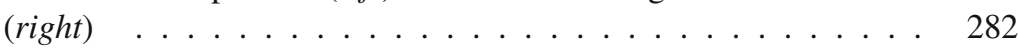

17.6 Observed image of scraper tow tracks . . . . . . . . . . 283

17.7 Population change of meiobenthos before and after experiment ....................... . . 284

17.8 Distribution of known active SMS sites in the western Pacific ....................... 286 
17.9 Structural outline of sulfur oxidizing in bacterial mat field (left) and bivalve field (right) . . . . . . . . . . . . . . 287

17.10 Comparison of food web structures around hydrothermal vent $($ left $)$ and in normal benthos $(r i g h t) \ldots . . . . . . . .287$

$18.1 \quad$ Project location . . . . . . . . . . . . . . . . . 299

18.2 Map of sea routes . . . . . . . . . . . . 300

19.1 Houses of the tunnel workers . . . . . . . . . . . . . . . . 314

19.2 Miners and engineers and woman tavern keeper . . . . . . . . . 317

19.3 Allegorical figure of a woman across a map of Europe . . . . . . 321

19.4 Mariga Perlongo . . . . . . . . . . . . . . . . . 323

21.1 Bingham Canyon Mine - "The richest hole on earth." . . . . . . . 354

21.2 Tailings piles - burying the landscape . . . . . . . . . . . 359

$22.1 \quad$ Location map of Angola with map of major cities and mining centers in northeastern Lunda region . . . . . . . 371

22.2 Alluvial mining pit in a deviated river course . . . . . . . . . . . 374

22.3 Maludi's diamond "comptoir," established during the 1950 s diamond rush . . . . . . . . . . . . . . . 374

22.4 Calonda Diamang's model of colonial architecture, common in the region's urban centers for the purpose of housing mining personnel . . . . . . . . . . . . 375

23.1 Map of Guatemala, showing the location of Marlin Mine (gold and sliver) and Fenix project (nickel and cobalt) . . . . . . 384

23.2 Map showing the location of major mines in the Philippines . . . . . . . . . . . . . . . . . 388

23.3 Extreme poverty in Guatemala . . . . . . . . . . . . . . 396

23.4 Poverty in the Philippines . . . . . . . . . . . . . . . . . 397

23.5 Vulnerability of the Philippines to El Nino Induced

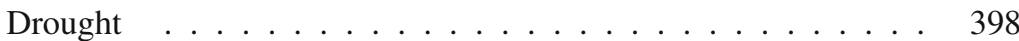

24.1 The Lebedinskoye iron ore deposit . . . . . . . . . . . . . 415

24.2 The algorithm used to assess the complex geoecological assessment of areas at the level of administrative units . . . . . 417

24.3 The ecological situation in the Starooskol'skiy and Gubkinskiy rayons (districts) . . . . . . . . . . . . . . . 422

25.1 Peatland regions and Bord na Móna bog works . . . . . . . . . . 431

25.2 Activities associated with the development of Bord na Móna peatlands . . . . . . . . . . . . . . 433

25.3 1940s hostel for temporary bog workers . . . . . . . . . . . . . 434

25.4 Peat milling machine. Spiked drums strip $1.5 \mathrm{~cm}$ (0.6 inches) of peat from bog surface . . . . . . . . . . . . . 436

25.5 Peat harvesting. Milled peat is collected in progressively larger piles prior to loading onto trains . . . . . . . . . . . . 436

25.6 Peat train. Peat trains, running on temporary tracks, transport peat from bogs to power stations or briquette factories . . . . . . . . . . . . . . . . 
25.7 Bord na Móna housing development under construction, early 1950s ... . . . . . . . . . . . . . . . . . 438

$25.8 \quad$ Rhode peat-fired power station c.1960 . . . . . . . . . . . . 439

25.9 Derrinlough peat briquette factor c.1960 . . . . . . . . . . . 441

26.1 Major recipients of Russian gas . . . . . . . . . . . . . . . 450

26.2 Supply of energy resources from Russia and the Caspian Sea area ..................... 456

26.3 EU Slovenia's pipelines - existing and proposed . . . . . . . . . 458

27.1 The oil sands of Alberta, Canada. The three areas Athabasca, Cold Lake, and Peace River - comprise the largest oil-sand deposits in the world. The amounts of recoverable oil in the deposits place Canada second only to Saudi Arabia in reserves.

27.2 Colorado oil shale prospective area bureau of land management areas of critical environmental concern . . . . . . . 464

27.3 Syncrude upgrader operations north of Fort McMurray, Alberta . 467

27.4 Blocks of sulfur produced during processing, stored at a Syncrude upgrader site north of Fort McMurray, Alberta. No use has yet been found for this a by-product of the

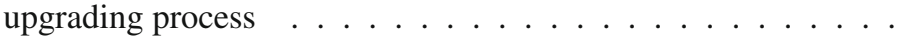

27.5 Parachute, $\mathrm{CO}$, situated along Interstate 70, looking north across the major oil shale fields of North America. Rifle is representative of the small towns in the area that will be susceptible to rapid growth. It had a population in July 2007 of 8,807 , an increase since 2000 of $23.6 \%$, largely as the result of the increased development of coal-bed methane and the resurgent interest in the prospect of oil shale development

27.6 Forest clearing and residential developments are part of the housing boom at Fort McMurray, Alberta . . . . . . . . . .

27.7 The need for housing is already evident in the area near Parachute, $\mathrm{CO}$ as a result of ongoing development of coal-bed methane and the resurgent interest in oil shale . . . . . . 471

27.8 The Callanish standing stones . . . . . . . . . . . . . . . . . 473

27.9 A protest poster declaring "If we plant these today, what will we plan tomorrow?" . . . . . . . . . . . . . . . . . . . . . . 474

27.10 SEGS (Solar Energy Generating Plant) at Kramer junction, west of Barstow, California. These installations are concentrating solar power facilities, using parabolic trough with single-axis tracking. They occupy a low-priority patch of land . . . . . . . . . . . . . . . . . . 478

28.1 Major oil pipelines and terrorist attacks . . . . . . . . . . . . 487

28.2 Oil import vulnerability . . . . . . . . . . . . . . . . 492

28.3 Percent reduction in import diversity . . . . . . . . . . . . . 492

28.4 Dependency on oil . . . . . . . . . . . . . . 493 
29.1 GM's answer to the Japanese - GoogleEarth image of the Spring Hill, Tennessee Saturn plant . . . . . . . . . . . . . 503

29.2 The Kama River, Kamaz Truck and FIAT plant the largest motor vehicle plant in the world seen in GoogleEarth. Originally, the total plant size was most of the rectangular area seen in this image - about 12 square miles (7,680 acres or just over 3,100 ha), with automotive operations extending to other parts of the city. This is more space than all the motor vehicle plants in France and almost as much as all those in Japan, though there is some boulevard and green space mixed in here . . . . . . . . . . . . . 504

29.3 GoogleEarth image of the Hiroshima Ujina complex (Mazda Manufacturing, 2009) . . . . . . . . . . . . . . 507

29.4 GoogleEarth image of the FAW Chanchun, Jilin works. Over 6,000 vehicles are parked to the southeast a testament to an undeveloped just-in-time system? The FAW Toyota works are just over a kilometer to the southeast . . . 509

30.1 North Karelia and its forest sector. The postcode areas are classified according to their socio-economic properties . . . . . 520

32.1 The interstate highway system in $1947 \ldots \ldots$. . . . . . . . 555

32.2 The interstate highway system in 2008. Metropolitan areas are shaded . . . . . . . . . . . . . . 556

32.3 Traffic levels on the interstate highway system, 2006 . . . . . . . 557

32.4 The interstate highway system in Birmingham, Alabama . . . . . 561

33.1 The extent of BR-230 . . . . . . . . . . . . . 570

33.2 Transamazon highway road sign ............ 573

33.3 The federal highway network in Amazonas . . . . . . . . . . . . 574

33.4 Port of Altamira on Xingu river . . . . . . . . . . . . . 575

33.5 Travessão or settlement road . . . . . . . . . . . . . . . . 578

33.6 The cadastral geometry of Transamazonia colonization . . . . . 579

33.7 Town of Uruara . . . . . . . . . . . . . . . . . . . . 580

33.8 Phase of construction for the Transamazonia highway (top) 1975, (middle) 1981, (bottom) 1999 . . . . . . . . . . . 583

33.9 Logging truck on unpaved Transamazonia highway . . . . . . . 584

33.10 Counties crossed by BR-230 in Pará and Amazonas . . . . . . . 586

33.11 Transamazonia colonist family . . . . . . . . . . . 586

33.12 Pastures where forests once stood . . . . . . . . . . . . . 588

33.13 Cadastral geometry and fishbone settlement . . . . . . . . . . 590

33.14 Protected areas in the Brazilian Amazonas . . . . . . . . . . . . 592

34.1 Proportion of projects on schedule (of total projects) . . . . . . . 602

34.2 Percentage of cost overrun . . . . . . . . . . . . . . 602

34.3 Environmental approval process . . . . . . . . . . . . 605

34.4 Land acquisition process under the land acquisition act of 1894 . 607

34.5 Golden Quadrilateral . . . . . . . . . . . . . . . . . . 610

$36.1 \quad$ Population distribution in Mongolia $2000 \ldots$. . . . . . . . . 630 
36.2 Transportation infrastructure of Mongolia . . . . . . . . . . 632

36.3 Projected population redistribution . . . . . . . . . . . . 635

36.4 Existing trade corridors of Northeast Asia (2001) . . . . . . . . . 637

36.5 Oil in and around Mongolia . . . . . . . . . . . . . . 638

37.1 (a-left) The ALSIB (Alaska-Siberia) route, showing airfields of the Northwest Staging Route (map courtesy of U.S. Air Force). (b-right) Map of overland routes to Alaska proposed at the outset of America's entry into World War II. The Alcan route, depicted as a solid black line and labeled with a circled "C," was chosen primarily because of its distance from potential enemy naval attacks and for its proximity to the Northwest Staging Route.

Alternative proposed routes $(\mathbf{A}, \mathbf{B}, \mathbf{D})$ are indicated, as is route of Canol Pipeline and Canol Highway from Norman Wells to Whitehorse. From Stefansson (1944b). These maps exemplify the cartographic approach of Richard Edes Harrison in depicting geographic relationships between World War II adversaries . . . . . . . . . . . . . . . 646

37.2 B-25 bombers and P-39 fighters at Ladd Field in Fairbanks, AK, awaiting transfer to Russia. The template for Soviet red star insignias used on the aircraft was obtained from a local Texaco gasoline station (Hays, 1996) . . . .

37.3 Map of Alcan Highway route in 1942, showing approximate locations of regimental sectors. Base map from Richardson (1942a: 82) . . . . . . . . . . . . . . . . 649

37.4 The sense of displacement and conjugal longing of young soldiers and engineers far from home is well expressed in this cartoon (of unknown origin) from the Herbert Warner collection, American Geographical Society Library, Golda Meier Library, University of Wisconsin-Milwaukee.

Warner was an employee of a private contractor retained by PRA . . . . . . . . . . . . . . . 650

37.5 Life along the construction route of Alcan pioneer road. (a-top left) Primitive camp with sawmill in early 1942. (b-top right) Bridge across a tributary of the Peace River. (c-bottom left) Opening ceremony of the Alcan Highway at Soldiers' Summit near Kluane Lake, Yukon Territory, approximately $100 \mathrm{mi}(160 \mathrm{~km})$ east of the Alaska border. (d-bottom right) Small bulldozer enmired in mud after thaw of ice-rich permafrost . . . . . . . . . . . . . . . .

37.6 Pioneer road construction techniques. (a) Because the roots of many trees do not penetrate permafrost, clearance of rights of way by bulldozers was a relatively easy task over much of the Alcan route. After clearance of felled timber and brush, the ground was scraped, promoting 
absorption of solar radiation and thaw of underlying ice-rich permafrost. Three of the seven U.S. Army regiments (93rd, 95th, 97th) involved in construction of the pioneer road were composed of African-American troops. (b) After a period of only several days, ablation of ground ice turned many rights of way into impassible quagmires. (c) Corduroy road construction used to mitigate damage caused by thaw of ice-rich permafrost. Timbers were obtained from slash created by road construction, and covered with brush and gravel to inhibit thaw. (d) Steep section of pioneer road with prominent road cuts

37.7 (a) Permafrost profile typical of terrain along the Alcan route. In areas of "warm" permafrost, in which mean annual temperatures are at or just below $0^{\circ} \mathrm{C}\left(32^{\circ} \mathrm{F}\right)$, the substrate is vulnerable to thaw induced by changes in the insulating layers of vegetation and organic matter at the ground surface. Taliks (unfrozen layers at the top of or within permafrost) may or may not be present, depending on site's climatic history and local conditions (b) Permafrost profile along a road through swampy terrain, showing the relation between surficial cover and depth to permafrost. Both diagrams appeared in Muller (1944)

37.8 (Top) "wrong" and (bottom) "right" methods for constructing roads in permafrost terrain (Muller 2008: 119) _ . . 656

37.9 Checkpoint at south end of Alaska Highway, fall 1943. Drastic improvements to the road in summer 1943 are apparent from the fact that Carlson traversed the entire highway using the two-wheel-drive staff car shown passing the checkpoint . . . . . . . . . . . . . . . 658

$38.1 \quad$ A map of the Hachula valley . . . . . . . . . . . . . . . 667

38.2 The KKL plan for draining the Hachula swamp . . . . . . . . . . 669

38.3 Route of the cross Israel road . . . . . . . . . . . . . . . . . 675

39.1 Gautrain route . . . . . . . . . . . . . . . . 687

39.2 Sign depicting Gautrain construction . . . . . . . . . . . . . . 688

39.3 Gautrain construction at Tambo international airport . . . . . . . 688

39.4 Logo promoting Gautrain . . . . . . . . . . . . . . . . 691

40.1 The central artery/tunnel project . . . . . . . . . . . . . . 698

40.2 The elevated central artery, $2001 \ldots \ldots$. . . . . . . . . . . 699

40.3 The same area after project completion, $2008 \ldots \ldots$. . . . . . 700

40.4 Boston harbor . . . . . . . . . . . . . . 702

40.5 Site of future pier and marina on Spectacle Island . . . . . . . . . 703

40.6 Erosion control walls on Spectacle Island made with sections of central artery . . . . . . . . . . . . . . . . 704 
40.7 Portion of the Rose F. Kennedy Greenway through downtown Boston . . . . . . . . . . . . . . . 710

41.1 The Bosphorus and immersed tunnel alignment (Belkaya, Ozmen, \& Karamut, 2008) . . . . . . . . . . . . . . . 716

41.2 Location of the study area . . . . . . . . . . . . . 717

41.3 Population change in Istanbul, 1927-2010. (TUIK, Turkish Statistical Institute) $\ldots \ldots$. . . . . . . . . . 718

41.4 Population change in Asian and European sides of Istanbul: 1935-2010. (TUIK, Turkish Statistical Institute) . . . . 719

41.5 Traffic congestion in Istanbul is getting worse with increasing car ownership and lack of efficient public transportation network (Ministry of Transportation) . . . . . . . 720

41.6 The plans of Bosphorus tunnel planned during the reign of Sultan Abdülmecid in 1860 . . . . . . . . . . . . . . 721

41.7 Alignment of the Marmaray project . . . . . . . . . . . 722

41.8 The Bored tunnel under construction in Marmaray project . . . . 723

41.9 Cross-section of the tunnels and stations between Yedikule and Söğütlüçeşme (Kadıköy) . . . . . . . . . . . . . . . . . 725

41.10 One of the ships that were excavated in Yenikapı . . . . . . . . 729

42.1 The Scandinavian links, indicating average traffic per day. (The fixed links are owned by Sund \& Bælt Holding $\mathrm{A} / \mathrm{S}$, which is owned by the Danish State. A/S Storebælt (Great Belt fixed links) and Femern Bælt A/S (coming Femern Belt fixed link) are owned $100 \%$ and Øresundsbro Konsortiet (Oresund fixed link) 50\% - the other 50\% is owned by the Swedish State.) . . . . . . . . . . . . . . . 736

42.2 The Great Belt East Bridge . . . . . . . . . . . . . . . . . . . 738

42.3 The Great Belt's East Bridge under construction . . . . . . . . . . 739

42.4 The Great Belt's East Bridge under construction . . . . . . . . . . 740

42.5 The Oresund Bridge, which opened for traffic in 2000 . . . . . . 741

42.6 The giant crane, Svanen (the Swan) is placing a bridge girder at the Oresund Bridge . . . . . . . . . . . . . . . 742

42.7 Construction of caissons for the Oresund Bridge at Malmo North Harbor . . . . . . . . . . . . . . . . . . . . . . . . . 743

42.8 One of several propositions for a bridge solution over the Femern Belt. The fixed link has been finally agreed upon by the governments and parliaments of Denmark and Germany and is stipulated to open for traffic in 2018 . . . . . . . 744

42.9 Diagram showing the traffic measured by vehicles per year 1990-2008 crossing the straits around the Danish island of Zealand . . . . . . . . . . . . . . . . . . 745

43.1 Location of the Qinghai-Tibet railroad . . . . . . . . . . . . . . 748

43.2 Permafrost distribution and mean annual ground temperatures along the higher parts of the Qinghai-Tibet Engineering Corridor . . . . . . . . . . . . . 
43.3 The four main embankment configurations of blocks used for cooling the rail-bed over permafrost on the Plateau . . . . . . 754

43.4 Crushed rock revetments in various configurations showing experimentation with different sizes of blocks . . . . . 754

43.5 Protective toe berms with thermosiphons stabilizing the slopes of the embankment in areas subject to flooding . . . . . . . 755

43.6 Transverse ventilation ducts with automatic shutters (at right) placed halfway up the side of the embankment . . . . . . 756

43.7 A section of railroad constructed on top of a permafrost (dry) bridge. The bridge shields the ground from direct insolation . . . . . . . . . . . . . . . 756

43.8 A passenger train traveling along the Qinghai-Tibet railroad . . . 757

43.9 Northern entrance to the Feghoushan tunnel at 4,906 m $(16,092 \mathrm{ft}) \ldots \ldots \ldots \ldots \ldots 758$

44.1 A hand-drawn social network: Positive and negative sociometric choices in a football team. Note: The nodes are team members; lines represent positive and negative feelings towards specific others. (Moreno, 1934: 213)

44.2 Number of social network articles published over time (values on the $y$-axis represent number of articles published in a given year; values on the $x$-axis represent years) . .

44.3 Number of citations to social network articles over time (values on the $y$-axis represent number of citations received by social network articles in a given year; values on the $x$-axis represent years) . . . . . . . . . . . . . . . . 772

44.4 Two representations of the "kite" network . . . . . . . . . . . 773

44.5 Three commonly used indexes of whole network structure . . . . 775

44.6 A whole network (left) and two ego networks (top and bottom right $)$. . . . . . . . . . . . . . . . . . . . . 776

$45.1 \quad$ Map of significant Bechtel projects in 2008 . . . . . . . . . . . . 784

45.2 Parody of Bechtel and BART on the cover of the San Francisco Bay Guardian in 1972 . . . . . . . . . . . . . 792

45.3 BART extension to Dublin-Pleasanton in San Francisco's East Bay suburbs, $2003 \ldots \ldots$. . . . . . . . . . . 795

45.4 Bechtel rail projects in the US . . . . . . . . . . . . . . . 796

45.5 St Pancreas Station, London - Barlow Shed . . . . . . . . . . . . 796

45.6 Portland MAX light rail extension to airport, 2008 . . . . . . . . 797

46.1 Floor space of building construction 2000-2005 . . . . . . . . . . 804

46.2 The sectors of the Chinese construction industry . . . . . . . . . 804

46.3 The legal framework of the Chinese construction industry . . . . 809

46.4 The process of DaiJianZhi projects . . . . . . . . . . . 811

46.5 Organization chart illustrating the use of the PMC/GCZCB approach in China . . . . . . . . . . . . . . . . . 811

46.6 Construction sectors promoted for foreign investment . . . . . . 814

47.1 Gulf corporation council countries . . . . . . . . . . 821 
47.2 Expatriate workforce population as a percentage of total workforce $2006 \ldots \ldots$. . . . . . . . . . . . . . 821

47.3 Construction site Oman . . . . . . . . . . . . . . 822

47.4 Construction site in Oman . . . . . . . . . . . . . . 823

47.5 Ajman international airport (left); and Dubai metro (right) . . . 823

47.6 The Pearl Qatar . . . . . . . . . . . . . . . . . . 824

47.7 The dynamic tower Dubai . . . . . . . . . . . . . . . . 825

47.8 Al Madina Azarqa (blue city) . . . . . . . . . . . . . . . . 825

47.9 Ajman international airport . . . . . . . . . . . . . . . . 826

47.10 Labor camp at Muscat . . . . . . . . . . . . . . . . . . . 827

47.11 Labor accommodations and Dubai migrant workers in a room . . 828

47.12 Khalifa city, Abu Dhabi . . . . . . . . . . . . 835

49.1 World container traffic and throughput, 1980-2008 . . . . . . 853

49.2 Traffic handled by the world's 20 largest container ports, 2007 . . 854

49.3 Europa container terminal, port of Antwerp . . . . . . . . . . . 856

49.4 Port container terminal facility . . . . . . . . . . . . . 857

49.5 Panamax containership, port of Le Havre . . . . . . . . . . . . . 858

49.6 Depth and surface distribution of a sample of container port terminals $(N=296) \ldots \ldots \ldots \ldots$. . . . . . . . . . . . . . . . . . . . 859

49.7 Intermodal rail facility . . . . . . . . . . . . . . . . 860

49.8 Economies and diseconomies of scale in container shipping . . . 862

49.9 The largest available containership, 1970-2008 (in TEUs) . . . . 863

50.1 Airport expansion in the Persian Gulf. At the end of the first decade of the 21st century, the Persian Gulf especially the $320 \mathrm{mi}(500 \mathrm{~km})$ crescent from Doha to Dubai, was home to several of the largest airport infrastructure building projects in the world . . . . . . . . . . . . 869

50.2 New airports of the Pearl River Delta. In the decade and a half after 1990, the Pearl River Delta witnessed perhaps the greatest regional expansion of airport infrastructure in the history of commercial aviation . . . . . . . . . . . 870

50.3 The new terminal 3 at Beijing capital international airport. As part of BCIA's “Move Under One Roof" program, members of the Star Alliance including Air China as shown in this photo have been located together in this a concourse of Terminal 3. The picture was taken beneath the wing of a departing 777 operated by Singapore

Airlines, another of the 15 Star Alliance members that operate from terminal 3 . . . . . . . . . . . . . . 872

50.4 Denver international airport. Since its completion in 1995, Denver international airport has become a symbol of the city and a significant engine of economic growth . . . . . . . . 874

50.5 Kansai internatioal airport. The artificial island upon which Osaka's new airport was constructed is connected to the mainland by a $3.7 \mathrm{~km}$ bridge. Despite weak traffic 
growth at the airport, a second runway was built on newly

reclaimed land visible to the right of the original island

in this image . . . . . . . . . . . . . . . . . 880

51.1 Minneapolis campus growth from 1911 (left) to 1996 (right) . . . 893

51.2 University of Minnesota twin cities . . . . . . . . . . . . 893

51.3 St. Paul campus growth from 1923 (left) to 1996 (right) . . . . . . 894

51.4 UMORE image from Sasaki plan . . . . . . . . . . . . . . . . 899

$52.1 \quad$ Worship service at Lakewood Church, Houston, TX . . . . . . . . 906

52.2 Megachurch locations within the United States . . . . . . . . . . 909

52.3 The shifting location of Megachurches . . . . . . . . . . . . . . . 909

52.4 Metropolitan Atlanta megachurches . . . . . . . . . . . . . . . 910

52.5 Attender concentration in one Atlanta megachurch . . . . . . . . 910

52.6 Interior design of Southeast Christian Church, Louisville, KY . . 912

52.7 James River Assembly, Springfield, MO . . . . . . . . . . . . . . 914

52.8 The crystal Cathedral, Garden Grove, CA . . . . . . . . . . . . . 914

52.9 The full sanctuary of Southeast Christian Church,

Louisville, KY . . . . . . . . . . . . . . . . . . . . 916

52.10 An aerial view of Southeast Christian Church, Louisville, KY . . 917

52.11 The literal and figurative churchscape of Southeast

Christian Church, Louisville, KY ～. . . . . . . . . . . . 917

52.12 Re-creation of a small town setting in Liberty Church,

Worcester, MA _. . . . . . . . . . . . . . . . . . . 919

52.13 Youth and educational wing mural at Faith Church,

New Milford, CT . . . . . . . . . . . . . . . . . . . . . . . 922

52.14 Expressive and media-driven worship at Ray of

Hope Christian Church, Decatur, GA and Saddleback

Community Church, Lake Forest, CA . . . . . . . . . . . . . . . 925

52.15 One church in 13 locations - the expansive campus of

LifeChurch, Oklahoma City, OK . . . . . . . . . . . . . . . . 927

52.16 The internet campus of LifeChurch, Oklahoma City, OK . . . . . 927

$53.1 \quad$ Plan of Moskva Siti lots . . . . . . . . . . . . . . 935

53.2 Skyline of Moskva Siti as seen from Vorobiovy Hills in the summer of 2007. The highest structure is the Tower on the Quay (268 m; $879 \mathrm{ft}$ ). Notice how much larger the project is relative to everything else, including one of J. Stalin skyscrapers. Newer towers are even larger . . . . . . . . 940

53.3 The Ring road in St. Petersburg (KAD) at its full planned extent with the planned Western Speedway (ZSD) running north-south. The Baltic Pearl is southwest of the main port area . 943

53.4 The major projects planned for the central city area in St. Petersburg . . . . . . . . . . . . . . . . . . . . . . 944

53.5 The winning design for the Gazprom tower from RMJM as displayed publicly in November 2006 . . . . . . . . . . . . . . 946

53.6 The Baltic Pearl business center with a residential complex going up in the background . . . . . . . . . . . . 
54.1 Burj Dubai dwarfing surrounding buildings, May 2007 . . . . . . 956

54.2 The Dubai world trade centre, Dubai's first skyscraper . . . . . . 958

54.3 Burj Al Arab photographed from Wild Wadi Water Park . . . . . 960

54.4 Billboard advertising Downtown Dubai, featuring young Europeans and East Asians . . . . . . . . . . . . . . . . . . 964

55.1 One of floating city project . . . . . . . . . . . . . . . . 968

$55.2 \quad$ Project having an underwater part . . . . . . . . . . . . . 969

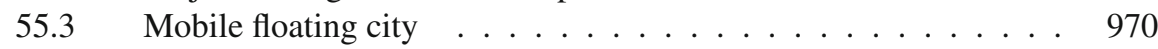

55.4 Stationary position of floating city . . . . . . . . . . . . 971

55.5 Freedom ship (different views) . . . . . . . . . . . . 973

55.6 Cutting of floating platform from ice field. Notations: 1 - ice field in arctic (Antarctic) ocean; 2 - small tractor with band-saw or slicing wire saw; 3 - mechanical band saw or slicing wire saw . . . . . . . . . . . . 975

55.7 Ice platform prepared for floating city. (a) Common view, (b) Cross-section of platform. Notations: 1 - ice; 2 - top heat protection; 3 - low (bottom) heat protection and floating support (inflatable air balloon); 4 - cooling tubes

55.8 Floating city on ice platform: (a) Open floating city, (b) Floating city closed by film. Notations: 5 - city; 6 - protection from ocean waves in storm; 7 - turning connection (joint) of separated ice platform;

8 - fully-rotation azimuth thruster propellers; 9 - film dome ...................... 977

$57.1 \quad$ Kazakhstan: Centered in Astana . . . . . . . . . . . . . . . 1006

57.2 Astana and Kazakhstan relative to Eurasia. Its location is near the geographic center of Eurasia, a point that the country's national airline, Air Astana, makes in its ads (Yacher, 2009c: 18). . . . . . . . . . . . . . . . . 1007

57.3 High-level schematic of agents and inputs to the Astana

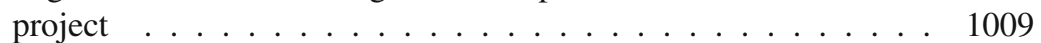

57.4 The Pyramid . . . . . . . . . . . . . . . 1011

57.5 Baiterek, the symbol of Astana. In the background is the Akorda . . . . . . . . . . . . . . . . . . . . . . . . . 1012

57.6 KazMunaiGaz. To the right is the ministry of communications. In the background one can notice the construction equipment being used to build Khan Shatyr . . . . . 1012

57.7 Modern sculpture denoting Kazakh art . . . . . . . . . . . . 1013

57.8 The monument honors the epic hero Kenesary Khan (1841-1847), recently elevated to the status of a freedom fighter for his defiance of the Russian empire

57.9 Children are being engaged in the process of extolling the virtues of Astana. Posters and various advertisements show not only the futuristic Astana but its global presence. More often than not the Kazakh language is used in these 
outdoor messages. In the lower right is the commonly used advertizing symbol celebrating the tenth anniversary of Astana's existence as the Capital: Baiterek . . . . . . . . . . . 1014

57.10 The rate of construction can be considered intense. Even as the economic crisis has affected Kazakhstan, building of governmental agencies has not abated

57.11 New housing has been constructed at a fast pace. Though large in size, these buildings totally ignore the Soviet era block building designs

57.12 In old Astana, a number of residential buildings have not changed since independence. The inside quality of the buildings remain in disrepair . . . . . . . . . . . . . . . . 1016

$58.1 \quad$ Location of the new capital, Pyinmana (Naypyidaw) . . . . . . . 1022

58.2 Jungles and mountainous terrain of Pyinmana . . . . . . . . . . . 1027

58.3 Constructing civilian apartments in Naypyidaw . . . . . . . . . 1030

58.4 Myowma market in Naypyidaw . . . . . . . . . . . . . . . 1031

58.5 Myowma market in Naypyidaw . . . . . . . . . . . . . . . 1031

58.6 Residential blocks in Naypyidaw . . . . . . . . . . . . . . . . . 1032

58.7 Future Naypyidaw bus station complexes . . . . . . . . . . 1033

58.8 City hall in Naypyidaw . . . . . . . . . . . . . . . . . . 1033

58.9 Urban communities and transport networks around the new capital . . . . . . . . . . . . . . . . . . . . 1035

$58.10 \quad$ Urban landscape of central Pyinmana . . . . . . . . . . . . . . 1035

58.11 Urban landscape of Naypyidaw . . . . . . . . . . . . . . . 1036

58.12 Plan for fountain construction in Naypyidaw . . . . . . . . . . . 1036

58.13 Military parade ground in Naypyidaw command center . . . . . . 1037

58.14 Yezin dam and agricultural areas in Northeastern Pyinmana . . . 1039

58.15 Senior general Than Shwe and three monarchical monuments: Anawratha (left), Bayinnaung (middle), and Alaungpaya (right) . . . . . . . . . . . . . . . . 1039

58.16 One of secret tunnels in Myanmar . . . . . . . . . . . . . . . . . 1042

60.1 An aerial view of the sustainable public administration town-as-a-hill (S-PATH) for South Korea . . . . . . . . . . . . . 1058

60.2 Land use plans of the three major levels in the S-PATH: Level 4-Platform Level, Level 7, and Level 10-Grand Concourse (shown in Roof/Site Plan) 1062

60.3 (Top) The Eastern sloped elevator links the lakefront park and the stepped gardens to the Grand Concourse on Level 10. (Bottom) The Western "Tube" is the main hub for the Bus Rapid Transit System and the main pedestrian artery on the West . . . . . . . . . . . . . . . . . . . . 1063

$61.1 \quad$ Location of selected edge cities in North East US . . . . . . . . . 1076

61.2 Edge cities with median household income in Charlotte MSA, North Carolina . . . . . . . . . . . . . . . . . . 1079

61.3 Southpark, Charlotte, North Carolina area looking to west . . . . 1080 
61.4 Eastern section of college place, Charlotte, North Carolina . . . . 1081

61.5 Typical building in Ballantyne village office park in Charlotte, North Carolina . . . . . . . . . . . . . . . . . . . 1082

61.6 Street view of Santa Fe, Mexico . . . . . . . . . . . . . . . 1083

62.1 Mammoth Cave National Park, Kentucky. "Enrollees brushing and rolling top surface of road leading to residence and utility areas, April 11, 1938."

62.2 The American recovery and reinvestment act in Lexington, Kentucky . . . . . . . . . . . . . . . . . 1091

62.3 "Enrollees prepare to transplant shrubs and sod, March 1, 1937."

62.4 Actual and predicted unemployment rates under ARRA.

After Romer and Bernstein (2009) . . . . . . . . . . . . . . . . . 1104

63.1 Housing Development Board estates . . . . . . . . . . . . 1111

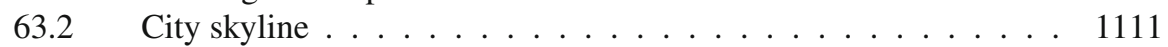

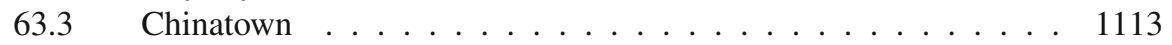

63.4 Kampong Glam . . . . . . . . . . . . . . . . . . . . 1114

63.5 Esplanade-Theatres on the Bay . . . . . . . . . . . . . . 1116

63.6 Marina Bay Sands: Back view . . . . . . . . . . . . . . . 1117

63.7 Marina Bay Sands: View from bay Aerial . . . . . . . . . . . 1118

$63.8 \quad$ Orchard Road . . . . . . . . . . . . . . . . . . . . 1119

64.1 The location of the new town of Marne-La-Vallée and of Val d'Europe (sector IV) . . . . . . . . . . . . . . . . . . 1128

64.2 The extent of Val d'Europe and the area developed by the Walt Disney Company (as Eurodisney SCA) . . . . . . . . . . . . . . . . . . . . . . . . 1129

64.3 Modernist architecture of public buildings, Serris town hall . . . 1133

64.4 Hiding the back stage of Disney's theme parks . . . . . . . . . . 1137

64.5 An old village street and its traditional architecture . . . . . . . . 1140

64.6 The "valley shopping centre" (selling luxury goods at "factory outlet" prices), copying "traditional" French village architecture . . . . . . . . . . . . . . . . . . . . . . . 1140

65.1 Mission Bay aerial photo . . . . . . . . . . . . . 1152

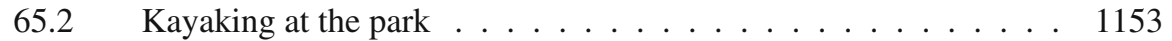

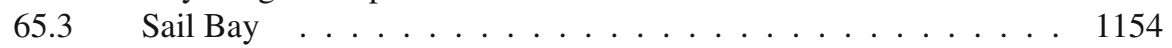

65.4 Map of Mission Bay ................. 1156

66.1 The royal and ancient club house, St. Andrews, Scotland . . . . . 1161

66.2 Old Tom Morris's son, Young Tom Morris, like his father an Open Champion, wearing The Open Championship's original prize, the Champions Belt. . . . . . . . . . . . . . 1162

66.3 Old Tom Morris . . . . . . . . . . . . . . . . . . . 1163

66.4 Building a golf course by hand in the "Golden Age." . . . . . . . 1163

66.5 The "Double-Loaded" fairway . . . . . . . . . . . . . . . . . 1167

66.6 Plan view of core development . . . . . . . . . . . . . 1168

66.7 The integrated golf course, South Florida . . . . . . . . . . . 1170 
66.8 Tools of the modern course builder . . . . . . . . . . . . . . 1171

66.9 A Florida fairway . . . . . . . . . . . . . . . . . . . . 1172

66.10 Sand hills, Western Nebraska: A contemporary example of a "natural site." . . . . . . . . . . . . . . . . . . 1173

66.11 A rendered master plan . . . . . . . . . . . . . . . . . 1174

66.12 Whistling straits-Hole \#7 . . . . . . . . . . . . 1175

66.13 Whistling straits_-after and before. Creativity and megaengineering applied to a stark canvas. . . . . . . . . . 1176

66.14 Bay Harbor, Michigan: Golf and Marina: A created golf course . . . . . . . . . . . . . . . . 1177

66.15 Grading a mountainside . . . . . . . . . . . . . 1179

66.16 Mass grading plan for a par 5 golf hole. Typically provided in 100 scale. Centerline indicated by SW/NE line . . . . 1180

66.1730 -scale detail green drawing . . . . . . . . . . . . . . . . . 1181

66.18 Illustrative cut and fill map . . . . . . . . . . . . . . . . . . 1183

66.19 Subsurface modeling . . . . . . . . . . . . . . . 1183

66.20 The impacts of severe weather. Storm damage to a newly

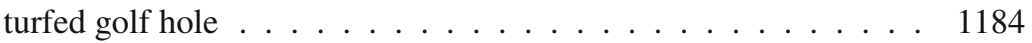

66.21 Dubai sports city . . . . . . . . . . . . . . 1185

66.22 Large contemporary construction site during megaengineering . . 1188

66.23 The results . . . . . . . . . . . . . . . . . . 1188

67.1 Riverdale zoo monkey cages, 25 September 1913 . . . . . . . . 1200

67.2 Metropolitan zoo map, 1992, showing three project locations . . . 1206

67.3 Gorilla rainforest very early concept plan . . . . . . . . . . . . 1207

67.4 African Savanna very early illustrative concept 1987 . . . . . . . 1209

67.5 African Savanna project, baobob tree . . . . . . . . . . . . . 1211

67.6 Consultation about Tundra Trek project with Inuit elders at Baker Lake in Nunavut, Canada . . . . . . . . . . . . . . . . . 1212

67.7 Hudson bay coast entrance, bowhead whale skeleton entrance, Tundra Trek design . . . . . . . . . . . . . . . . . . . . 1213

67.8 Hudson bay coast Tundra Trek project (a) Freighter Canoe for field research; (b) Field sketch of the region . . . . . . . . . . 1214

67.9 African Savanna field trip by Toronto zoo staff . . . . . . . . . . 1215

67.10 Models and sketches used in Toronto zoo projects:

(a) African Savanna Lion Kopje Model; (b) Gorilla Rainforest Concept Sketch, Dja Reserve Research Station;

(c) Hudson Bay Tundra Trek Project Sketch; (d) Inuit Node Design Sketch, Tundra Trek Project.

68.1 The Great Limpopo Transfrontier Park, part of the larger Great Limpopo Transfrontier Conservation Area . . . . . . . . . 1224

68.2 Southern entrance gate to Mozambique's Limpopo National Park ................... 1225

68.3 Transfrontier parks (TFPs) and transfrontier conservation areas (TFCAs) in the Southern African Development Community (SADC) 
68.4 "Wilderness" image for tourist consumption in South Africa's Kruger National Park

68.5 Relocation of rhinoceros from South Africa to restock the Limpopo National Park with wildlife. The international border fence between Mozambique and South Africa is shown. The truck carrying the rhinoceros is waiting for the Mozambican authorities to clear the appropriate paperwork so that the truck can pass from South Africa into Mozambique . . . . . . . . . . . . . . . . . . . . 1234

68.6 Preparing release of the rhinoceros in Mozambique a few kilometers beyond the border fence . . . . . . . . . . . . . 1235

68.7 Released rhinoceros in Mozambique . . . . . . . . . . . . . 1236

69.1 The Mekong region with Chinese development projects discussed in the chapter . . . . . . . . . . . . . . . . . . . . 1244

69.2 Map of dams built with the involvement of Chinese companies and banks, 2008 . . . . . . . . . . . . . 1245

69.3 A page from Golden Boten City's brochure for investors . . . . . 1251

69.4 Shops at Golden Boten City . . . . . . . . . . . . . . . . . . 1252

69.5 Namtha Grand Hotel, Luang Namtha, under construction, in 2009 . . . . . . . . . . . . . . . . . . . . . . . 1254

$70.1 \quad$ Location map of Cap Cana . . . . . . . . . . . . . . . . . 1272

70.2 Portion of Trump-Cap Cana billboard located along road that climbs up to resort . . . . . . . . . . . . . . . . . . 1276

70.3 Photographic collage of Cap Cana and Trump Farallón. Upper left, clockwise: The allure to the Dominican Republic, but especially Cap Cana, is the powdery beaches; earth-moving equipment has created, allegedly, the largest inland marina in the world, as well as a reconfigured shoreline and lagoons to accommodate the new golf courses; prospective buyers climb elevated decks on each lot to get a sense of the view and surrounding areas; access to the Trump bluffs was made possible (besides the helipad) by a four-lane highway with a manicured median strip. Road construction also exposed the cavernous bedrock, ideal for promoting a wine cellar that can be part of each of the 65 Trump Farallón sites . . . . . . 1278

70.4 Marketing mix of Cap Cana, Punta Cana Hotel \& Resorts, and all-inclusive resorts

70.5 Welcome center atop Trump Farallón, with view of Cap Cana and ocean . . . . . . . . . . . . . . . . . . 1280

$72.1 \quad$ Streets with equine themed names . . . . . . . . . . . . . . 1298

72.2 Ecological regions of Kentucky _. . . . . . . . . . . . . 1299

72.3 Regions defined by various organizations . . . . . . . . . . 1301

72.4 Bird's eye view of the principal breeding farms of the bluegrass region of Kentucky, 1900 . . . . . . . . . . . . . 1304 
Manchester farm . . . . . . . . . . . . . . . . 1306

72.6 Stone fence along Pisgah Pike, Woodford County . . . . . . . . 1306

72.7 Plank fencing on Rice Road, Fayette County . . . . . . . . . . 1307

72.8 Effect of urban service boundary . . . . . . . . . . . . . . . . 1309

72.9 Bluegrass country driving tour map clipping and LCVB web page header . . . . . . . . . . . . . . . . 1315

72.10 Festival market building, downtown Lexington . . . . . . . . . 1316

72.11 Architectural details at Hamburg Pavilion . . . . . . . . . . 1317

72.12 Thoroughbred park . . . . . . . . . . . . . . . 1318

72.13 Bluegrass airport . . . . . . . . . . . . . . . . . . . . . . 1319

72.14 Lexington-Fayette county detention center . . . . . . . . . . . 1320

73.1 Location of horsefarms in Upper Hunter region . . . . . . . . 1324

73.2 Thoroughbreds in a paddock of irrigated, green grass in summer . . . . . . . . . . . . . . . . . . . . . . . 1329

73.3 Ornate main entrance to Patinack farm . . . . . . . . . . 1330

73.4 Bunting in the center of Scone promoting the town as the horse capital of Australia . . . . . . . . . . . . . . . 1334

73.5 Male and female toilets near the tourist information center in Scone . . . . . . . . . . . . . . . . . . . 1334

73.6 Billboard linking horse riding and water quality issues in the Upper Hunter region

73.7 Billboard showing coal mining to be a dusty activity that destroys vegetation and the rural landscape . . . . . . . . 1335

75.1 Indonesia. The rotation period for industrial tree plantations in Indonesia is only seven years. Fast growing trees, mainly Acacia mangium and Eucalyptus species, are planted for pulp and paper production . . . . . . . . . . 1355

75.2 The Indonesian case study area is located in the Sanggau and Sintang districts, West Kalimantan, Indonesia . . . . . . 1356

75.3 Zimbabwe. Small-scale eucalyptus woodlots owned by the local farmers are common in Southern Africa . . . . . . . . . . 1358

75.4 Zimbabwe. When the woodlots are used as grazing areas trees can often suffer from damages made by grazing animals and especially goats. In this case the coppice stems may be in safe place high above the ground

75.5 Local communities' perceptions of tree plantation project benefits in Ghana (modified from Blay et al., 2007) . . . . . . . . 1362

75.6 Degraded forests (left) have smaller amount of trees and tree species than forest gardens (right) which include some planted trees . . . . . . . . . . . . . . . . . . . 1363

76.1 Percent forest-cover loss in the Eastern United States, pre-1800s to 1909 .

76.2 Cumulative enrollment in the conservation reserve program in Indiana, 1986-2007 
76.3 Enrollment in the conservation reserve program in 1997 and net change in enrollment over the next decade

77.1 A severely eroded field typical of large areas on the Southern Piedmont and other areas of the eastern US in the 19th and early 20th centuries . . . . . . . . . . . . . . 1384

77.2 A field in Wilshire, UK, 1995. Despite the long and steep slopes, the fact that the furrows run up and down the slope, and the lack of any erosion control methods, there is no apparent erosion . . . . . . . . . . . . . . . . . . . . . 1384

77.3 Average annual precipitation compared to precipitation intensity, UK and eastern US. Note that while averages are similar, intensities are much greater in the US . . . . . . . . . 1385

77.4 Infiltration capacities of soil vs. average rainfall rates, UK and eastern US. Note that excesses in the US are several times those in the UK . . . . . . . . . . . . . . . . 1386

77.5 Before and after soil conservation engineering, Coon Creek, Wisconsin. Top: Early 1934. Note rectangular fields and gully systems extending into upland fields. Bottom: 1967. Note contour strip cropping . . . . . . . . . . . . . 1388

77.6 Former cropland, now reverted to forest, Southern Piedmont. The forested land is either too eroded for cultivation or is simply economically marginal to better cropland elsewhere in the US. Such reverted land is common and even dominant in many areas of the eastern US . .

77.7 Productivity and efficiency of agricultural land use, 1947-1994. Note that land area declined about $10 \%$ but productivity increased almost $150 \%$. . . . . . . . . . . .

79.1 Sheikh Zayed bin Sultan Al Nahyan (1918-2004) was the leading figure in the greening ambitions . . . . . . . . . . . . . . 1414

79.2 The covers of two environmental magazines demonstrate the Emirati flag as a central feature in the greening efforts

79.3 An illustration of ecological modernization in the Gulf. The picture is from a cover of an environmental show and illustrates a sick earth in a hospital bed surrounded by four male doctors curing the earth with modern technology . . . . . . 1418

80.1 Yarra Bend Asylum from Studley Park . . . . . . . . . . . . . . . 1425

80.2 Yarra Bend and Kew Asylums (right), 1900-1910 . . . . . . . . . 1428

80.3 Map of Melbourne showing geographical location and size of Yarra Bend and Kew Asylum sites (shaded areas at upper right) in relation to general hospital sites (circles) . . . . 1429

80.4 Map of Yarra Bend Asylum, 1855 showing the location of original buildings in relation to river and public roads . . . . . 1430

80.5 Yarra Bend Lunatic Asylum, 1864 . . . . . . . . . . . . . . . . . 1433

80.6 Metropolitan hospital for the Insane, 1869 . . . . . . . . . . . . 1433 
$80.7 \quad$ Kew Asylum, $1889 \ldots \ldots$. . . . . . . . . . . . . . . . . . . . 1434

$80.8 \quad$ Yarra Bend cottages, $1861 \ldots \ldots \ldots$

80.9 Track to Asylum, Kew, $1920 \ldots \ldots$. . . . . . . . . . . . . . 1436

80.10 Looking toward Zig Zag Bridge and Kew Asylum from site of stables, $1927 \ldots$. . . . . . . . . . . . . . . . . 1436

80.11 Collingwood from the town hall tower . . . . . . . . . . . . . 1437

$81.1 \quad$ Scheme of the textile barrage (side view) . . . . . . . . . . 1444

82.1 The Williams channel rectification plan . . . . . . . . . 1455

$82.2 \quad$ Sketch of the Leland Neck cutoff . . . . . . . . . . . . . . . . 1458

82.3 Cutoff Locations from Arkansas to Louisiana . . . . . . . . . . . 1461

83.1 Overview of northwestern Europe showing the location of the Netherlands at the southern fringe of the North

Sea Basin. Adjacent regions are rich in relief and have older geological formations exposed with respect to the Netherlands (arrow) . . . . . . . . . . . . . . . . . . . . . . 1466

83.2 Schematic diagram shows change in reaction of historic humans against rising sea level and coastal hazards.

Box 1. Zuiderzee works, Box 2. Delta works . . . . . . . . . 1468

83.3 General map of the Netherlands and locations of mega-scale engineering works . . . . . . . . . . . . . . . 1468

83.4 Map shows location, nature and size of the different projects of the Zuiderzee Works in the central north of the Netherlands that were carried out between 1927 and 1975.

(Cf. Table 83.1)

83.5 The final stage of completing the Closure Dike (Afsluitdijk) in 1932

83.6 The $32 \mathrm{~km}(20 \mathrm{mi})$ long Closure Dike has not really changed shape since the completion in 1932, in spite of modern busy traffic as this photograph from 2006 shows

83.7 Impact of the 1953-flooding disaster in Zeeland causing about $400 \mathrm{~km}(250 \mathrm{mi})$ of dike to breach and flooding at least $1,920 \mathrm{~km}^{2}$ (475,000 acres)

83.8 The location, nature and size of the different projects of the Delta works in the Southwestern Netherlands and shows the years when they were completed

83.9 Delta Works: The Storm Surge Barrier is built with a number of large slides held in between piers which can be moved. Normally, the slides are lifted in order to reduce the tides' impacts, except for extra high tides or during severe storm surges when the slides can be entirely lowered . . . 1477

84.1 The Netherlands coast -800 A.D. . . . . . . . . . . . . . . . . 1482

84.2 The Netherlands coast -1250 A.D. . . . . . . . . . . . . 1483

84.3 The Netherlands coast -1600 A.D. . . . . . . . . . . . . . . 1483

84.4 The Netherlands coast - Present . . . . . . . . . . . . . . . . . . 1484

84.5 Map of the Zuiderzee reclamation . . . . . . . . . . . . 1487 
Map of the Delta project . . . . . . . . . . . . . . . . . . . . 1490

84.7

Haringvliet sluice

85.1 Schematic of SNWT routes (west, central, east).

$\mathrm{DJK}=$ Danjiangkou, site of intake for central route . . . . . . . 1501

85.2 Elevation profile of Eastern route . . . . . . . . . . . . . . 1502

85.3 Artist's rendering of parallel tunnels crossing underneath the Yellow river. Similar tunnels will also be part of the central route . . . . . . . . . . . . . . . . . 1503

85.4 Workers constructing part of the tunnel to cross under the Yellow river . . . . . . . . . . . . . . . . . . . . . . . 1504

85.5 Workers increasing the height of the Danjiangkou Dam in 2008

86.1 Mean flow of USSR rivers ( $\mathrm{km}^{3}$ /year). Chart A indicates percentage of the USSR's territory with river discharge into specified sea and ocean basins. Chart $\mathbf{B}$ indicates percentage of USSR's average annual river discharge accounted for by rivers flowing into specified sea and ocean basins. Numbers above the bars indicate drainage basins: 1-Arctic Ocean; 2-Pacific Ocean; 3-Black and Azov seas; 4-Baltic Sea; 5-Caspian and Aral seas

86.2 Final diversion plans for European and Siberian parts of USSR (1984). European Diversions: numbers 1-3-first stage, first phase $\left(19.1 \mathrm{~km}^{3}\right)$; number 4-first stage, second phase $\left(10.2 \mathrm{~km}^{3}\right)$; number 5-second phase $\left(37.7 \mathrm{~km}^{3}\right)$.

Siberian Diversions: 6-First phase $\left(27.2 \mathrm{~km}^{3}\right)$; 6-7 second phase $\left(32.8 \mathrm{~km}^{3}\right)$

88.1 Routes for the pipelines connecting Caspian Sea to Aral Sea, with altimetry shown (m)

89.1 Port Augusta to Lake Eyre Pipeline Corridor. A slightly different course might prove better if only the South Basin is to be filled at the Lake Eyre terminal south of the proposed Goyder Channel Tension Textile Dam . . . . . . . . . . 1550

89.2 Volume/elevation curve of the Lake Eyre . . . . . . . . . . . . . 1552

89.3 Tube-wall thickness via wall safety tensile stress for different tube diameters and water pressures . . . . . . . . . 1553

89.4 Specific pumping power dependence on water speed and pipe diameter . . . . . . . . . . . . . . . . . . . 1555

89.5 Eyre North and South monthly evaporation rates . . . . . . . . 1558

90.1 Circular map with China highlighted . . . . . . . . . . . . 1570

90.2 Oblique map of the Yangtze River . . . . . . . . . . . . . . . . . 1572

90.3 Satellite photos of the Yangtze River dam site: (a) 1987,

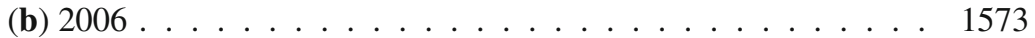

90.4 Map of Three Gorges Dam site features . . . . . . . . . . . . . 1579 
91.1 The Three Gorges reservoir area. . . . . . . . . . . . . . . . . . . 1584

91.2 Counties of the 11 provinces where TGP migrants were resettled in 2000-2004 . . . . . . . . . . . . . . . . . . . 1589

91.3 Annual number of migrants displaced to 11 provinces (2000-2004).

$92.1 \quad$ Location of Itaipú dam . . . . . . . . . . . . . . . . 1600

$92.2 \quad$ Aerial view of the spillway and the powerhouse. . . . . . . . . 1600

92.3 View of the Penstocks. . . . . . . . . . . . . . . . . . . . 1604

92.4 Schematic of the Itaipú dam showing the dam across the Parana River, the extensive earthworks on the Eastern (Brazilian) side, and the often-spectacular spillway on the Western (Paraguayan) side that allows for diversion of water when the water level in the reservoir is high. . . . . . . . . 1611

$93.1 \quad$ Eleven river basins in Nigeria. . . . . . . . . . . . . . 1618

93.2 The Tiga dam - Nigeria's largest dam for irrigation . . . . . . . . 1622

94.1 Course of the Mekong river . . . . . . . . . . . . . . . . 1634

94.2 The Mekong cascade 1987. The main difference from the 1970 plan was the reduced height of the giant Pa Mong Dam. . . . 1636

94.3 Dams on the Mekong River and its tributaries, as of July $2008 \ldots \ldots$

94.4 National Geographic's December 1968 cover story, "River of Terror and Hope" (left), graphic representations of the terror and hope. . . . . . . . . . . . . . . . . . . . 1640

94.5 Dam protest in Bangkok . . . . . . . . . . . . . . . . . 1646

95.1 How big is Africa. (Trustees of Boston University, n.d. and The White Horse Press, Isle of Harris, 2006) . . . . . . . 1653

95.2 1890s map of Livingstone falls showing Inga falls curve. . . . . . 1654

95.3 Inga I and II Dams in Nkokolo valley. . . . . . . . . . . . . 1667

95.4 Proposed Pan-African electricity grid . . . . . . . . . . . . 1668

95.5 Proposed Grand Inga electricity corridors ("highways"). . . . . . 1670

$96.1 \quad$ U.S. military academy, West Point, New York. . . . . . . . . . 1685

96.2 Army troop deployments in the U.S., 1860 . . . . . . . . . . . 1685

96.3 Army troop deployments in the U.S., 1867 . . . . . . . . . . 1686

96.4 Current photograph of the remnants of Fort Union, NM, an historic western Army fort . . . . . . . . . . . . . 1686

96.5 Current photography of the remnants of Fort Laramie,

96.6 Map of the Armor Warfare Center Maneuvers in the USA, 1940s (Bischoff, 2008) . . . . . . . . . . . . . . . . . 1688

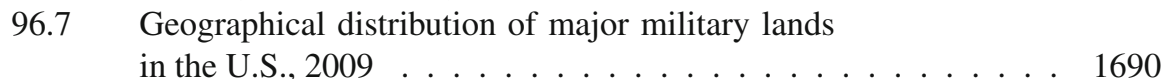

$96.8 \quad$ Ecoregional distribution of Army lands in the U.S. . . . . . . . . 1693

96.9 Cantonment and training areas on Fort Bliss (left) and Fort Hood (right), Texas . . . . . . . . . . . . . . . . . . . . . . . 1694

96.10 Fort Lewis cantonment area . . . . . . . . . . . . . . . . 1695 
97.1 Phases of U.S. acquisition of Mexican land. . . . . . . . . . . . . 1705

97.2 Existing and proposed fencing projects along the Mexico-U.S. border. . . . . . . . . . . . . . . . . . . . . . . 1709

97.3 Border Fence, Lighting, and Patrol Roads. . . . . . . . . . . . . . 1710

97.4 Border areas affected by REAL ID act waivers. . . . . . . . . . . 1712

97.5 Example of pedestrian fencing, Arizona. . . . . . . . . . . . . 1713

97.6 Border wall construction along levees in Rio Grande River Valley, Texas. . . . . . . . . . . . . . . . . . 1713

97.7 Construction filling in Smugglers' Gulch, California. . . . . . . . 1715

97.8 Mesh fencing with Debris-Filled Grates, Hidalgo County, Texas. The high water mark reached seven feet. . . . . . . . . . 1715

97.9 Mesh fencing, after debris was cleared. Taken at the same location as Fig. 97.8. Comparison shows that debris was piled at least $2 \mathrm{ft}(0.6 \mathrm{~m})$ high at the grates. . . . . . . . . . . 1716

98.1 Island locations for Australia Asylum seeker detention. . . . . . . 1732

98.2 ÜNHCR map of "Australia's Excision Zone" . . . . . . . . . . . . 1735

98.3 Location of detention centers in Australia and offshore Islands. . . 1738

98.4 Alcatraz down under: Christmas island detention center. . . . . . 1739

98.5 The Babies Compound: Details of Child Care, Education Units . . 1741

98.6 Caged area for "detainee relaxation" . . . . . . . . . . . . . . 1741

98.7 Caged lights . . . . . . . . . . . . . . . . . . . 1742

98.8 Entrance . . . . . . . . . . . . . . . . . 1742

98.9 Christmas Island CCTV security room . . . . . . . . . . . . . 1743

99.1 View from a scenic overlook in Wise County. Wallens Ridge stands at the center . . . . . . . . . . . . . . . . 1750

99.2 Map of the Wallens Ridge state prison study area . . . . . . . . . 1751

99.3 The costly road to Red Onion State Prison winds up and around the mountain for several miles, at a $10 \%$ grade in some places . . . . . . . . . . . . . . . . 1753

99.4 High-pressure sodium lamps that light Wallens Ridge are visible for miles . . . . . . . . . . . . . . . . . . . . 1757

99.5 Boundary of the Red Onion State prison property. . . . . . . . . . 1759

100.1 Location of Le Havre nuclear reprocessing plant. . . . . . . . . . 1766

100.2 Coastline of La Cotentin Peninsula . . . . . . . . . . . . . . . 1766

100.3 Satellite image of the Le Havre plant. . . . . . . . . . . . . . . . . 1767

100.4 The Le Havre reprocessing plant . . . . . . . . . . . . . . . . . 1770

100.5 Rural landscape surrounding Le Hague plant . . . . . . . . . . . 1771

100.6 Dairy farming on La Cotentin Peninsula . . . . . . . . . . . . . 1773

100.7 Rugged and bleak coastal landscape near the reprocessing plant ........................ 1776

101.1 Location of Semipalatinsk, Kazakhstan, the nuclear test site, detonation sites, and communities adjacent. . . . . . . . . 1791

101.2 Physical landscape adjacent to and in the Polygon . . . . . . . . 1792

101.3 Magnitude of blasts and directions of radioactive clouds blasts. . . 1794 
101.4 Diorama of the testing area, 29 August 1949 in the Science

Museum, Kurchatov . . . . . . . . . . . . . . . . . . . 1795

101.5 Levels of radiation of sites adjacent to and downwind from the SNTS. . . . . . . . . . . . . . . . . . 1796

101.6 Medical college in Semipalatinsk . . . . . . . . . . . . . . . 1797

101.7 Book cover E. L. Yakubovskya et al. Semipalatinsk Test Polygon (2003) . . . . . . . . . . . . . . . . . . . . . . . . . . . 1799

101.8 Drawing of one child from Semipalatinsk "How I see my city" . . . . . . . . . . . . . . . . . . . 1808

101.9 Monument to victims of nuclear testing, Semipalatinsk . . . . . . 1808

101.10 Display in the Ethnographic Museum, Semipalatinsk . . . . . . . 1809

101.11 Semey Artist: Alexander Shevchenko and one depiction of the Polygon . . . . . . . . . . . . . . . . . . 1811

101.12 Abandoned buildings in Kurchatov . . . . . . . . . . . . . . . . 1813

101.13 Open border crossing to the Polygon (formerly restricted entry) . . . . . . . . . . . . . . . . . 1814

102.1 Location of retirement communities in Florida and South Florida . . . . . . . . . . . . . . . . . . 1824

102.2 Aerial photo of Century Village, Pembroke Pines . . . . . . . . . 1826

102.3 Main entrance to Century Village, Pembroke Pines . . . . . . . 1826

102.4 Housing in Century Village, Pembroke Pines . . . . . . . . . . . 1827

102.5 Century Village, West Palm Beach. Note contrast in housing and landscaping with Century Village, Pembroke Pines . . . . . . . . . . . . . . . . . . . . . . . 1828

102.6 Century Village, Pembroke Pines, Shuffleboard Court . . . . . . 1828

102.7 Century Village, Pembroke Pines, Clubhouse . . . . . . . . . . . . 1829

102.8 Century Village, Trolley Transportation Service Provided . . . . 1829

102.9 Sun City Center development plan . . . . . . . . . . . . . . . . . 1830

102.10 Sun City Center, single family dwelling . . . . . . . . . . . . . 1831

102.11 Sun City Center, lawn bowling . . . . . . . . . . . . . 1831

102.12 Gated entrance to Jewish retirement community in Delray

Beach ...................... 1834

102.13 Jewish community, Kiryas Joel, of Satmar Chasidic Sect . . . . . 1839

102.14 Finnish Lutheran Church in Lantana . . . . . . . . . . . . . . . 1840

102.15 Finnish community center in Lake Worth . . . . . . . . . . . . . 1841

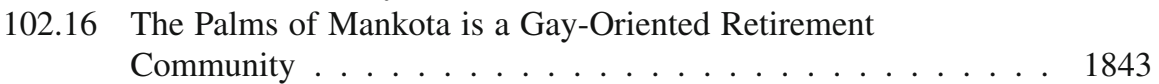

102.17 Emergency medical services are a common site in retirement communities . . . . . . . . . . . . . . . . . 1846

102.18 Century Village, Pembroke Pines, apartments with
elevators that replaced outside staircases $\ldots \ldots \ldots$
$18 \ldots 48$

102.19 Offices of medical specialists are seldom far from retirement communities . . . . . . . . . . . . . . 1850

103.1 Abandoned house in Detroit, haphazardly and inadequately secured 
103.2 Detroit population density by census tract, 1950. . . . . . . . . 1861

103.3 Detroit population density by census tract, 2000. . . . . . . . . . 1862

103.4 Abandoned, fire-damaged house in Detroit . . . . . . . . . . . . 1862

103.5 Non-market and weak-market areas in Youngstown, Ohio. . . . . 1863

103.6 Abandoned factory building in Detroit . . . . . . . . . . . . . 1864

103.7 Abandoned storefronts in Cleveland . . . . . . . . . . . . . 1865

103.8 Vacant Packard Motor Car Company plant in Detroit. . . . . . . . 1866

103.9 Street scene on Cleveland's East Side. . . . . . . . . . . . . . . . 1869

103.10 Abandoned church in Detroit . . . . . . . . . . . . . 1870

103.11 Old Cleveland Board of Education building, now largely overgrown by vegetation. . . . . . . . . . . . . . 1871

103.12 The DeQuindre Cut in Detroit: a rail line turned into an inner-city walking and bicycling path. . . . . . . . . . . . . 1872

103.13 Map of culverted streams and watersheds in Cleveland. . . . . . . 1872

104.1 Local schoolchildren watch as a rural house is connected. . . . . . 1888

104.2 Advertisement seeking peat for a peat-fired generating station (Kerryman, March 23, 1957) . . . . . . . . . . . . . . . . 1889

104.3 Linesmen and cable drum. Most of the work of the rural electrification program in the late 1940s used locally recruited manual labor. . . . . . . . . . . . . . . . . . . . . 1891

104.4 Construction crew. . . . . . . . . . . . . . . . . . . . 1891

104.5 Crew erecting pole (horse in background). . . . . . . . . . . . . 1892

104.6 Stringing the new wires. . . . . . . . . . . . . . . 1892

104.7 One of the most important benefits of electricity on the farm: the electric pump replacing the old water pump in the center picture. The mobile sales van is visible in the background. . . . . . . . . . . . . . . . . . . 1893

104.8 ESB map showing areas completed by 1952. . . . . . . . . . . . 1894

104.9 An REO wall map showing the early geographical progress of electrification in 1948. . . . . . . . . . . . . . . 1896

104.10 The formal switch-on ceremony headed up by local clergymen. The new meter box is visible in the background as is the smoke patch from the now-obsolete paraffin lamp. . . . . . . . . . . . . . . . . . . . . . . . 1897

104.11 Exhibition of appliances for farm use. There is particular emphasis on "cheap" electricity. . . . . . . . . . . . . . . . . . . 1898

105.1 Map of Tennessee Valley Region and TVA dams. . . . . . . . . . 1901

105.2 Norris Dam, Tennessee Valley, 2008. . . . . . . . . . . . . . . . 1910

105.3 A sea of white faces in this photograph of workers at Norris Dam, 1933. . . . . . . . . . . . . . . . . 1911

105.4 Layout of Norris planned community. . . . . . . . . . . . . . . . 1912

106.1 Early coal mining areas of Harlan County. . . . . . . . . . . . . 1918

106.2 Harlan County with communities of Benham and Lynch. . . . . . 1920

106.3 Benham, Kentucky . . . . . . . . . . . . . . . . . 1922

106.4 Lynch, Kentucky . . . . . . . . . . . . . . . . . 1923 
106.5 Lynch amusement building . . . . . . . . . . . . . . . . . 1924

106.6 Benham YMCA and hotel (background left) _. . . . . . . . . 1924

106.7 International Harvester company police in Benham . . . . . . . 1925

106.8 Lynch homes . . . . . . . . . . . . . . . . . . . . . . . 1927

106.9 Benham homes . . . . . . . . . . . . . . . . . . . . . . 1927

106.10 Lynch Superintendent's home . . . . . . . . . . . . . . . . . 1928

106.11 Original Benham store replaced in 1920 . . . . . . . . . . . 1929

106.12 First united mine workers union meeting in Lynch . . . . . . . 1931

107.1 South African provinces and capitals in relationship to former Bantustans. . . . . . . . . . . . . . . . . . . . . . . . . 1943

107.2 Port Elizabeth legacy residential areas. . . . . . . . . . . . . . . 1945

107.3 South end in its heyday. . . . . . . . . . . . . . . . . . . 1946

107.4 South end: a heterophobic townscape . . . . . . . . . . . . . . 1947

107.5 District Six, Cape Town in 2009. . . . . . . . . . . . . . . . . . 1948

108.1 Locations of select historic settlements on the Chukchi

Peninsula, 1900-1970 (villages mentioned in the text are labeled . . . . . . . . . . . . . . . . . . . . . . . . . . 1961

108.2 Location of contemporary settlements on the Chukchi Peninsula, 2008 . . . . . . . . . . . . . . . . 1962

108.3 Soviet-style houses in Lorino. . . . . . . . . . . . . . . . . . 1965

108.4 Remains of the relocated village (1977) of Nuniamo in 2008. . . . 1966

108.5 Contemporary hunting camp next to the abandoned village of Nuniamo. . . . . . . . . . . . . . . . . . . . . . . . . . . . 1969

109.1 1885 Map of Salt Lake City including Mormon wards the arrow (circled) between the 13th and 18th wards is pointing to Temple Square. . . . . . . . . . . . . . . . . . . . 1981

109.2 Mormon settlements and stakes in 1869 . . . . . . . . . . . . 1983

109.3 Former Zions co-operative mercantile institution (ZCMI) in Franklin, Idaho ． . . . . . . . . . . . . . . . . . . . 1985

109.4 Manti temple in Manti, Utah . . . . . . . . . . . . . . . . . . . 1987

109.5 Logan Utah Tabernacle . . . . . . . . . . . . . . . . . . . 1988

109.6 LDS Chapel in Mink Creek, Idaho erected in 1928 (“Colonel's twins" design) . . . . . . . . . . . . . . . . . . . 1990

109.7 Church headquarters in downtown Salt Lake City, with Temple Square in the middle block. . . . . . . . . . . . . 1992

110.1 The sign at the entrance to Raffles Girls' Primary School . . . . . 1999

110.2 Street sign marking Raffles Girls' Primary School _. . . . . . . 2000

111.1 Reference map. . . . . . . . . . . . . . . . . . . . . . . . . . 2014

111.2 Road sign . . . . . . . . . . . . . . . . . . . . . . . . 2016

111.3 Population trends in Nagorno Karabakh. . . . . . . . . . . . . . 2021

111.4 Number of toponyms by linguistic association. . . . . . . . . . . 2024

111.5 Spatial distribution of toponyms by linguistic association. . . . . 2026

111.6 Stepanakert in its many forms. . . . . . . . . . . . . . . . . 2027

112.1 U.S. military assists displaced persons in the wake of a Central American natural disaster. . . . . . . . . . . . . . 2033 
112.2 Afghan villagers view satellite image. . . . . . . . . . . . 2039

112.3 Satellite image of Kabul District 7. . . . . . . . . . . . . . . . 2040

112.4 Old cadastre map of Kabul. . . . . . . . . . . . . . . . . . . . . . 2041

112.5 Complexities and conflicts resulting from different types of tenure. . . . . . . . . . . . . . . . . . . 2044

112.6 Hand drawn parcels sketch in San Luis Potosi, Mexico. . . . . . . 2045

115.1 The Irish border region . . . . . . . . . . . . . . . . . . . . 2092

115.2 Application of development typologies to the Irish border region. (a) Application of the OECD typology - areas

about 12 m either side of the border; (b) NUI Maynooth's rural typology as applied to the area about $12 \mathrm{~m}$ either side of the border . . . . . . . . . . . . . . . . . . . 2092

115.3 Symbols of a political-religious divide include commemorating fallen comrades . . . . . . . . . . . . 2093

115.4 Religious affiliation along the Irish border. (a) Percent Protestant; (b) Percent Catholic . . . . . . . . . . . . . . . . 2094

115.5 The old customs hut on the Pettigo-Tullyhummon (Donegal/Fermanagh) border . . . . . . . . . . . . . . 2096

115.6 Map showing road closures spanning the North Monaghan/South Tyrone Border. The three images are of cratered roads that once spanned the North Monaghan/South Tyrone border. (C) Fr. Sean Nolan, Truagh Development Association . . . . . . . . . . . . . 2096

115.7 The dearth of rail crossings in the Irish border region . . . . . . 2098

115.8 The military check-point beside the GAA pitch

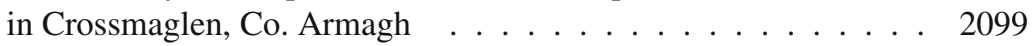

115.9 Postal service delivery challenges . . . . . . . . . . . . . . . 2100

115.10 Service delivery challenges: Currency exchange . . . . . . . 2100

115.11 The role of art in peace. The Lough McNean sculpture trail . . . 2104

115.12 Cross-border collaboration through partnership . . . . . . . . . 2104

115.13 Importance of various funding streams to local regeneration in the Irish border region . . . . . . . . . . . 2107

117.1 Baselines and Meridians for U.S. rectangular public land survey system . . . . . . . . . . . . . . . . . 2127

117.2 Township and range in the RPLSS . . . . . . . . . . . . . 2127

117.3 Sections and fractional sections in the RPLSS . . . . . . . 2128

117.4 New states proposed by Thomas Jefferson in the Northwest territory . . . . . . . . . . . . . . . 2130

117.5 U.S. state and county boundaries _. . . . . . . . . . . 2131

117.6 Center Pivot irrigation and the RPLSS in Kansas. . . . . . . . . 2132

117.7 Huron County, Michigan Road Network . . . . . . . . . . . . 2134

118.1 European influence in the world. . . . . . . . . . . . . . 2140

118.2 Cartoon of Cecil Rhodes spanning Africa. . . . . . . . . . . . . 2147

118.3 Time sequence map of Colonial Australia. . . . . . . . . . . . . 2149 
118.4 Aboriginal claimant applications as of 2009 in Australia, with rectilinear pattern of the Torrens system evident. . . . . . . . 2150

118.5 Triangulation lines in India and arcs of Great Trigon, Survey of India.

121.1 Global temperature anomalies based on four multiproxy and tree ring reconstructions for the period A.D. 900-2005. . . . 2186

121.2 Concentrations of carbon dioxide, methane and nitrous oxide for the past 10,000 years.

121.3 Climate model simulations of global temperature anomalies with (a) and without (b) anthropogenic increases in greenhouse gases.

121.4 Temperature increases associated with three IPCC 2007 AR4 scenarios. . . . . . . . . . . . . . . . . . 2191

121.5 Projected changes to major components of the hydrologic cycle associated with anthropogenic climate change.

122.1 Concentration in meq $\left[\mathrm{Ca}^{2+}+\mathrm{Mg}^{2+}\right]$ in spring waters. Total carbon as $\mathrm{mg} \mathrm{CO}_{2} \ldots \ldots$. . . . . . . . . . . . 2202

122.2 Artist's impression of an olivine hill at the campus grounds of the Utrecht University . . . . . . . . . . . . . . 2204

123.1 The mean radius of earth is about $3,960 \mathrm{mi}(6,373 \mathrm{~km})$. By contrast the radius of the georeactor is only about $6 \mathrm{mi}(10 \mathrm{~km})$, although there is much uncertainty in that estimate. The georeactor, thought to reside within the inner core at the center of earth, is comparably simple in structure. The georeactor sub-core consists of the actinide fuel, the uranium and heaver fissionable elements, such as plutonium, formed by the fission process. The surrounding sub-shell, which is thought to be liquid or a slurry, consists of radioactive decay products and fission products. Heat produced by nuclear fission in the sub-core, causes convection in the sub-shell which will interact with the Coriolis forces produced by planetary rotation and act like a dynamo, a magnetic amplifier, generating the geomagnetic field (Herndon, 2007, 2009). . . . . . . . . . . . . 2210

123.2 Oak Ridge National Laboratory georeactor numerical simulation calculated ${ }^{3} \mathrm{He} /{ }^{4} \mathrm{He}$ ratios, normalized to the same ratio in air, as a function of time. For comparison, ranges of values are shown for helium ratios measured in samples from mid-oceanic ridges. Note the ascent of georeactor helium ratios approaching the present age of earth, indicated by the arrow. Georeactor helium ratios increase as the uranium fuel becomes depleted. Comparably high values are observed in certain deep-source lavas, such as those from Hawaii and Iceland, 
are evidence that the end of the georeactor's life is

approaching, although the time-scale is not precisely known. . . . 2212

124.1 Schematic of the runaway greenhouse scenario.

(1) Various planetary engineering techniques are used to warm volatile-rich regions on Mars; (2) carbon dioxide in the polar caps and the regolith starts to vaporize; (3) the thicker atmosphere warms the surface and hence causes a further release of gases. If positive feedback is strong enough, self-sustaining outgassing may occur as a result of a comparatively trivial forcing . . . . . . . . . . . . 2220

125.1 Habitable compositions for plants and for humans. Bar shows the minimum or maximum allowed for each gas as indicated by arrows. Envelope show total pressure required. (Based on data from McKay et al., 1991) . . . . . . . . 2230

125.2 Greenhouse warming as an amount of greenhouse gases added to present Martian atmosphere for fluorine gases as labeled. Dotted line is for an optimal combination of the four gases.

126.1 Thermohaline circulation .................... 2239

126.2 Broecker's carbon pie chart . . . . . . . . . . . . 2245

126.3 Pacala and Socolow's (2004) stabilization wedges . . . . . . . 2246

126.4 Geoengineering as substitute and supplement. . . . . . . . . . 2251 



\section{List of Tables}

2.1 The Seven Wonders of the ancient world _. . . . . . . . 18

2.2 "The New Seven Wonders," a 2007 list derived from worldwide popular vote. (New7Wonders Foundation,

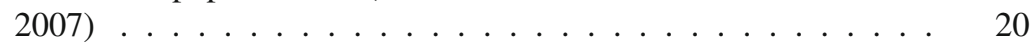

2.3 Examples of modern "wonders" in the U.S. organized by themes derived from the ancient Wonders . . . . . . . . . 22

4.1 The internet as a mega-project . . . . . . . . . . . 50

4.2 Mega-project Google: Portrait . . . . . . . . . . . 55

4.3 Nesting model for google as a mega-project . . . . . . . . 58

5.1 Examples of projects that make use of cloud collaboration . . . . 71

5.2 Ownership of selected cloud-collaboration projects . . . . . . 79

6.1 Facebook's 25 largest user countries . . . . . . . . . . . . 90

6.2 User feedback to facebook . . . . . . . . . . . . . . . . . 96

$8.1 \quad$ Key terms related to fiber optics . . . . . . . . . . . 116

8.2 Major trans-Atlantic and trans-Pacific fiber optics cables . . . . 121

9.1 A summary of urban WLAN provision in three Finnish cities ....................... 137

10.1 Activities while traveling measured in terms frequency and time intensity $\ldots \ldots \ldots \ldots \ldots \ldots \ldots$

$11.1 \quad$ Video game assemblages . . . . . . . . . . . . . . . . 165

12.1 Number of successfully obtained fixes, fix rates (\%)

13.1 Change in rural-urban distribution of cattle and buffaloes,

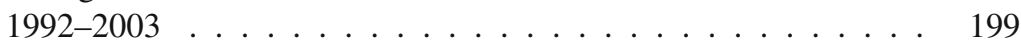

13.2 Proportion of total milk produced (in million tons) $\ldots \ldots \ldots$. . . 200

15.1 Grain production in the Soviet Union - 1922-1926

15.2 Gross state investment in agriculture 1953-1963 (in millions of rubles) . . . . . . . . . . . . . . . 246

17.1 Conditions and results of earlier economic feasibility

17.2 World metal production and abundance in earth's crust . . . . . . 291 
23.1 Mine location information for the Philippines . . . . . . . . 385

23.2 Ecclesial actions against mining in the Philippines . . . . . . . 389

24.1 Criteria and parameters used in the complex assessment of human-caused impacts on the areas of iron ore extraction

24.2 Assessment of the ecological situation in the areas of iron ore mining . . . . . . . . . . . . . . . . . . . 424

26.1 Oil and gas consumption of EU members . . . . . . . . . . . . 449

27.1 The total of installed and announced wind development projects in coastal Oaxaca by 2012. The total capacity is comparable to that installed in California by Jan 31, 2009, over a period of 35 years . . . . . . . . . . . . . . 475

$28.1 \quad$ Energy security outliers _ . . . . . . . . . . . . . . 494

29.1 Manufacturing plants $>700$ acres (283 ha). Plants are automobile production unless noted otherwise. Like numbers are in order of size . . . . . . . . . . . . . 500

29.2 Selected countries and total land in vehicle fabrication specifically comparing to Great Britain (excluding

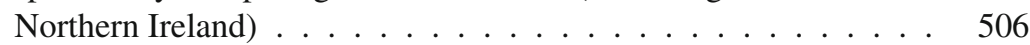

$30.1 \quad$ Forest residues by cutting alternatives in North Karelia . . . . . . 517

30.2 Forestry, the forest industries and socio-economic variables, by types of postcode area (see Fig. 30.1). Most of the information applies to $2005 \ldots \ldots \ldots 20$

30.3 Annual energy potential of forest residues and their refined products under two harvesting plans . . . . . . . . . . . 524

30.4 Potential effects on employment in forestry and transportation of exploiting forest residues in North Karelia, in person-years . . . . . . . . . . . . . . . 526

30.5 Estimated potential employment effects of sample plants in North Karelia with a composite residue log supply chain _ . . 528

31.1 The Saudi economic cities . . . . . . . . . . . . . . 540

31.2 Key special economic zones in operation or under construction in Dubai . . . . . . . . . . . . . . . . . 543

33.1 Build-up of the official highway system in Amazonia . . . . . . . 572

33.2 Cattle herd and population in the Transamazon Corridor, $2007 \ldots \ldots \ldots \ldots \ldots \ldots \ldots$

33.3 Unofficial road construction. Transamazon highway . . . . . . 589

34.1 Investment indicators in India . . . . . . . . . . . . . . . 602

37.1 Specifications for Alcan highway _... . . . . . . . . 653

37.2 Rates of Alcan highway construction during 1942 (after Sturdevant 1943: 180) . . . . . . . . . . . . . . . . 653

42.1 The world's biggest bridges as measured by free span $\ldots . . .736$

44.1 Centrality scores for nodes in the Kite network (generated by the network program UCINET [Borgatti, Everett, \& Freeman, 2002]) . . . . . . . . . . . . . . . . . . 781

$46.1 \quad$ Examples of mega infrastructure projects in China . . . . . . 806 
47.1 GCC member countries and their capital, population and area ....................... 822

47.2 Major projects by various property developers in GCC countries .................... 833

49.1 Technical changes in container port terminals . . . . . . . . . . . 864

$50.1 \quad$ World's leading passenger airports, $2007 \ldots \ldots$. . . . . . . . . . 868

50.2 The world's most expensive airports . . . . . . . . . . . . 871

50.3 The world's most expensive airport expansion projects, 2000-2010 ........................ 871

50.4 A comparison of the new airport terminals in Beijing and London . . . . . . . . . . . . . . . . . . . . . . 873

50.5 Scheduled airline capacity by region, 1998-2008 . . . . . . . . 875

51.1 Largest 15 public university campuses as of fall 2008 . . . . . 890

53.1 Data on Moskva Siti objects. (Compiled from various sources by authors $) \ldots \ldots . \ldots 937$

54.1 Tallest completed skyscrapers (October 2008) . . . . . . . . 956

55.1 Estimation of different variants of floating platforms . . . . . . 979

59.1 Land use legacies of Olympic and world's fair sites . . . . . . . . 1053

61.1 Selected megadevelopers by region in US . . . . . . . . . . . 1075

62.1 Allocation of federal recovery funds by sector in Kentucky . . . . 1091

62.2 WPA expenditures for projects completed to December 31, 1936 . . . . . . . . . . . . . . . . . . . 1093

$70.1 \quad$ Investment types and spatial impact of Cap Cana . . . . . . . . . 1274

72.1 Growth rates of bluegrass counties . . . . . . . . . . . . 1309

72.2 Gross domestic product by metropolitan area, 2005 and 2006 (millions of current dollars) . . . . . . . . . . . . . 1310

$72.3 \quad$ Selected equine related businesses in the Bluegrass . . . . . . . . 1311

75.1 Benefits of Eucalyptus camaldulensis woodlots under different ownership categories in Mukarakate, North-Eastern Zimbabwe (Tyynelä, 2001a) . . . . . . . . . . . . 1359

75.2 Number of trees and tree species are compared in different forest types in Begoro (moist semi deciduous area) and Dormaa (dry semi deciduous area) in Ghana . . . . . . . . . 1363

75.3 Three different forest plantation types and their main social impacts. Cases from modified taungya system in Ghana, small-scale eucalyptus woodlots in Mukarakate, Zimbabwe, and large scale industrial forest plantations in West Kalimantan, Indonesia _. . . . . . . . . . . . 1365

82.1 Mississippi river cutoffs in 1946 . . . . . . . . . . . . . . . . 1462

83.1 Areal and temporal dimensions of dikes and polders of the Zuiderzee works . . . . . . . . . . . . . . . . . . . 1471

86.1 Selected economic and environmental characteristics of the first stage Siberian water diversion project . . . . . . . . . 1521

89.1 Parameters for Port Augusta to Lake Eyre Pipeline . . . . . . . . 1555 
89.2 Monthly mean of daily global solar irradiation $\left[\mathrm{KWh} /\left(\mathrm{m}^{-2} \mathrm{day}^{-1}\right)\right] \ldots \ldots \ldots \ldots . . \ldots . . \ldots 1556$

89.3 Cost estimations . . . . . . . . . . . . . . . . . . . . . . 1560

91.1 Numbers of people actually displaced in the TGP by the end of $2005 \ldots \ldots$. . . . . . . . . . . . . 1585

91.2 Distribution of migrants displaced via GODR schemes (2000-2006) . . . . . . . . . . . . . . 1590

91.3 Numbers of migrants displaced to 11 provinces via GODR (2000-2004)

91.4 Per capita farmland and area of newly built housing of migrants resettled in 11 provinces . . . . . . . . . . . . . . . . . 1594

92.1 Credit Secured by Itaipú Binacional (EOY, 1983) . . . . . . . . . 1605

92.2 Debt of Itaipú Binacional (EOY, 1983) . . . . . . . . . . . . . . 1605

$92.3 \quad$ Debt of Itaipú Binacional (EOY 2006) . . . . . . . . . . . . 1606

92.4 Price of electric power . . . . . . . . . . . . . . . . . 1607

92.5 Gross Income from Itaipú: 1985-2005 ． . . . . . . . . . . . . . 1607

$93.1 \quad$ Dams and dam operations in Nigeria . . . . . . . . . . . . . 1621

93.2 Features of selected mega dams in Nigeria . . . . . . . . . . . 1623

95.1 Chronology of hydroelectric dams with hydroelectric generation capacity . . . . . . . . . . . . . . . . . . 1658

$95.2 \quad$ ICOLD Classification by dam wall height . . . . . . . . . . . 1659

95.3 African large hydroelectric dams $\geq 100 \mathrm{~m}$ in height . . . . . . 1660

95.4 Chronology of African mega hydroelectric dam reservoir capacity $(85$ dams $)$. . . . . . . . . . . . . . . . . . . . . 1661

95.5 Dam classification by reservoir surface area . . . . . . . . . . 1662

95.6 Chronology of African large and major dams by surface area . . . 1662

95.7 Summary: Number of African mega dams by classification system .

95.8 Chronology of African dams' installed capacity before 1960

96.1 Analogs of Army installations and world-wide operational areas

97.1 Costs of border fence from 1997-2008 in millions of dollars

97.2 Regulations and laws waived by homeland security secretary Chertoff 2006-2008

97.3 Reported number and causes of death along Mexico-US Border, FY 1998-2005.

$98.1 \quad$ Number of unauthorized boat arrivals . . . . . . . . . . . . . . 1725

98.2 Refugee humanitarian program, visas by category 1993/1994 to 2007/2008

98.3 Expenditure on offshore asylum seeker management on Nauru and Manus Island to end May 2002

98.4 Estimated expenditure for offshore asylum seeker management 2001/2002 
98.5 Detainees on Nauru and Manus island 2001-2007 . . . . . . . . 1737

98.6 Outcome of processing of offshore entry persons 16 September $2002 \ldots \ldots$. . . . . . . . . . . . 1737

$102.1 \quad$ Florida retirement communities . . . . . . . . . . . . 1825

103.1 Population of principal United States shrinking cities 1950-2007 . . . . . . . . . . . . . . . 1858

107.1 1960 Port Elizabeth residential areas; populations forced to move . . . . . . . . . . . . . . . . . . . . . . . 1945

107.2 Selected South African place name changes . . . . . . . . . . . . 1950

108.1 Selection of relocation events on the Chukchi Peninsula . . . . . 1964

110.1 Distribution of building names: raw figures . . . . . . . . . . . 2005

110.2 Distribution of building names: Percentages . . . . . . . . 2006

114.1 Breakdown of 2004-2006 Schengen facility funding (in million $€$ ) . . . . . . . . . . . . . . . . 2073

114.2 Slovenia: structure of border crossings per sectors, 1992-2002 ...................... 2082

114.3 Selected characteristics of borders of the Republic of Slovenia, 2002 . . . . . . . . . . . . . . . 2083

$115.1 \quad$ Locations at which citizens currently access services . . . . . . 2101

115.2 Location of the closest service by distance (irrespective of border) . . . . . . . . . . . . . . . . . . 2101

122.1 Composition $(\mathrm{mg} / \mathrm{l})$ of Loutraki mineral water, experimental water made by reacting a sparkling table water with olivine powder, and average magnesium bicarbonate waters . . . . . . . . . . . . . . . 2202

126.1 Geoengineering? Engineering earth, seas, and sky . . . . . . . . 2242

126.2 Stabilization wedges-Pick 7 . . . . . . . . . . . . 2246

126.3 Pleasures of paleolithic life . . . . . . . . . . . . . 2247 